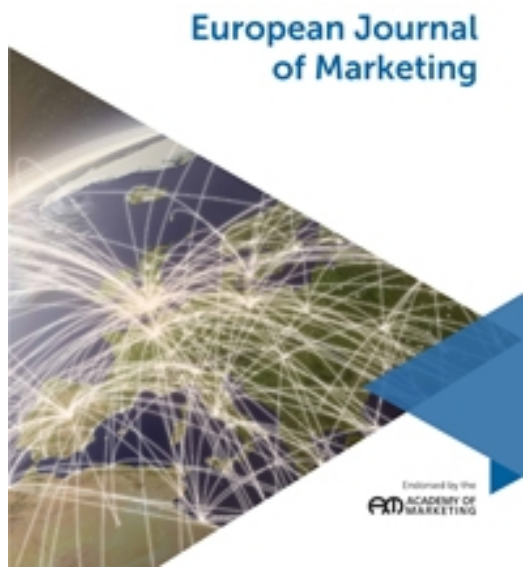

THE INFLUENCE OF A COUNTRY'S BRANDS AND INDUSTRY ON ITS IMAGE

\begin{tabular}{|r|l|}
\hline Journal: & European Journal of Marketing \\
\hline Manuscript ID & EJM-06-2018-0414.R4 \\
\hline Manuscript Type: & Original Article \\
\hline Keywords: & country image, brand, industry image, memory schema \\
\hline \multicolumn{2}{|l}{} \\
\end{tabular}

SCHOLARONE Manuscripts 


\title{
The influence of a country's brands and industry on its image
}

\author{
Structured Abstract \\ Purpose - Extant research has largely treated country image (CI) as an exogenous variable, \\ focusing mostly on its consequences on consumers' evaluations and purchases of products or \\ brands originating from a country. Scant research has examined the instrumental role of a \\ country's brands and products in the evaluations of CI. This study investigates how the brands \\ of a country contribute to CI ratings and the conditions underlying their effect on CI. \\ Design/methodology - Three experimental studies test the hypotheses, one pertaining to the \\ effect of brands on $\mathrm{CI}(\mathrm{N}=227)$, the second to the effect of products on $\mathrm{CI}(\mathrm{N}=116)$, and the \\ third to the effect of brands and products on industry image $(\mathrm{N}=215)$. The experimental \\ approach overcomes the limitations of cross-sectional surveys commonly used in CI studies to \\ detect the direction of the observed effects. Furthermore, a sample of British consumers were \\ allowed to determine the brands and products associated with a country.
}

Findings - Drawing on memory schema theory, across three studies, the authors identify two types of reverse inferences: from brand to CI and from product category to CI. The reverse inference from brand to superordinate image is stronger for industry image than for CI.

Research limitations - This research focuses on consumers' evaluations from only one country (the United Kingdom). Further research could replicate the studies across different countries and with different countries of origin (COOs). Researchers could also examine the influence of brands misidentified with the wrong $\mathrm{COO}$ and mistakenly stored as such in consumers' memories.

Practical implications - The results are relevant for managers and consultants working with country- (place-) branding campaigns. Brands and industries can help strengthen the evaluations of the economic dimension of different countries; however, these assets are 
underdeveloped in country-branding campaigns. Linking countries with brands and industries in campaigns could result in positive associations, which in turn could enhance the reputational rating of the countries.

Originality/value - This research extends previous studies on the effects of a country's products and brands on CI by incorporating the mediating role of industry image between brands/products and CI, separating the effects of brand and product category on CI, allowing consumers to determine which brands and products are associated with a country, and adopting an experimental methodology to ascertain the causal direction of the effects.

Keywords: country image, brand, industry image, memory schema 


\section{Introduction}

In 2017, the French foreign ministry honored the chief executive officer of LVMH for promoting his country's economic prestige (Mimosa 2017). Similarly, in 2015, Marca España, a governmental organization in charge of promoting the image of Spain abroad, gave an award to the chief executive officer of the information technology export company Libelium for contributing to the enhancement of the image and reputation of Spain (Libelium 2015). The contribution of globalized local companies to the promotion of country image (CI) is largely recognized by governments around the world. This contribution is not always positive, however, as the emission scandal involving Volkswagen shows. According to a Brand Finance study, the value of Germany's reputation has decreased by $4 \%$ since the Volkswagen scandal (Löhr 2015). Furthermore, only a handful of studies have provided some evidence for an effect of either country's brands (e.g., Kim and Chung 1997; Magnusson et al. 2014; White 2012) or product categories (e.g., Lee et al., 2016) on different aspects of CI (general and product-related CI); however, the focus of these studies has been limited to only one country industry (e.g., Kim and Chung 1997; Lee, Lockshin, and Greenacre 2016), the negative effects of company transgressions (e.g., Magnusson et al. 2014), the effect of prototypical brands or industries (e.g., White 2012; Lee Magnusson et al. 2014; Lockshin, and Greenacre 2016), and the lack of a theoretical basis (e.g., Kim and Chung 1997).

Furthermore, existing empirical studies reveal some inconsistencies. Magnusson et al. (2014) find that prototypical brands of a country affect the product-related CI but not the general image of economically advanced countries. Lee, Lockshin, and Greenacre (2016) find that congruent (to the country) product categories have a positive effect on the general CI of an advanced economy. Additionally, there are ecological validity concerns about the findings of those studies as the identified effects are restricted to preselected brands and industries (Kim and Chung 1997; White 2012; Magnusson et al. 2014; Lee et al. 2016). Additionally, 
they focus on negative effects (Magnusson et al. 2014), which are subject to negativity bias (see Ajzen, 2001) and inflate attitude measurements.

The current research aims first, to address the methodological limitations of past studies using an improved experimental approach; and second, to improve our theoretical understanding on the sequence that brand image evaluations spillover to industry image and, subsequently, to CI. The methodological approach the study uses is based on a mixed effects experimental design that assesses memory-based evaluations with spontaneous evaluations of image. The study provides a theoretical explanation of the image evaluation transfers between brand and CI that is grounded on memory-schema theory. It contributes to international marketing literature in four ways: (1) by incorporating the mediating role of industry image between brands and CI, (2) by separating the effects of brand and product category on CI, (3) by allowing consumers to determine which brands and products are associated with a country, and (4) by adopting an experimental methodology to ascertain the causal direction of the effects.

Prior research has used memory schema theory to justify the difference in the attitudinal evaluation of CI (e.g., Lee et al. 2016; Magnusson et al. 2014). However, the memory schema about a country has been assumed to trigger image evaluation with the mere presence of a stimulus cue (a brand or a product from the assessed country). A schema is a "cognitive structure that represents organized knowledge about a given concept or type of stimulus" abstracted from prior experience (Fiske and Taylor 1984, p. 139) and has an associative network structure (Ghosh and Gilboa 2014). The current research evaluates the assumption that consumers' CI evaluations are based on schemas (in the form of country associations) about the country stored in memory and that these schemas are automatically activated. In particular, we use Hastie and Park's (1986) theory on memory schema and the distinction between memory-based and online judgments to compare memory-based 
evaluations of a country with spontaneous evaluations of a country's image. Memory-based evaluations of a country can be elicited by retrieving brands of that country from memory. Thus, the difference between the two types of evaluations should determine whether the recalled brands affect CI evaluations.

Another assumption previous studies have made is that every consumer's schema will include the brands or products selected by the researcher as stimuli and that these stimuli will be equally salient to all individual consumers' schemas. Rather than an a priori selection of specific industries and brands as possible sources of CI, the presence of products and brands in a consumer's memory schema of a country is determined by that consumer's free recall. Research (e.g., Balabanis and Diamantopoulos 2008; Samiee et al. 2005) highlights the dangers of forcing respondents to evaluate prespecified brands to establish country-of-origin (COO) effects and acknowledges that consumers struggle to link many brands with their COO. Previous studies also recognize the methodological issues involved when respondents are told in advance the origin of brands under evaluation (Andéhn and L'Espoir Decosta, 2016). The current study addresses this problem by allowing a sample of British consumers to reveal the brands or products they have in their associative networks of a country.

By using the aforementioned approaches, we establish whether a country's brands have an effect on $\mathrm{CI}$ and expose the locus of the effect (i.e., which brands have the most influence on CI). Determining how a country's brands contribute to shaping the country's image is crucial both theoretically and managerially. Doing so aids in the development of a more discriminate, refined, and evidence-based configuration of CI evaluation frameworks. Understanding the makeup of a country's image and the contribution of each element can shed more light on the mechanisms underlying COO effects and help identify the elements of CI that are critical to the activation of such effects. Finally, the results of this study help 
practitioners improve the accuracy of their predictions about the outcome of CI-building or nation brand equity programs and better allocate resources in nation-branding campaigns.

The structure of this study is as follows: We first discuss the theories related to our topic and justify our hypotheses. This is followed by the three studies that test our hypotheses, after which we discuss the findings. Finally, we examine the implications and limitations of our findings and provide avenues for further research.

\section{Theoretical background and hypotheses}

\section{Importance and conceptualisation of CI}

The importance of CI has been recognized as early as the 1950s and 1960s (Perlmutter, 1954;

Schooler, 1965). Since then, there have been several academic approaches to conceptualization, decomposition, and measurement. Roth and Diamantopoulos' (2008) review of the literature finds that $\mathrm{CI}$ affects intended behavior toward the country (e.g., intended tourist visits, intended ties with the country, evaluations of and purchase intentions toward products of a country). Josiassen et al.'s (2016) calculation of the average regression coefficient of destination image on the willingness to recommend finds moderate positive size effects. However, as Hsieh et al. (2004), Josiassen et al. (2008), and Josiassen et al. (2013) highlight, CI's effects on behavior and intended behavior toward the country are not unmoderated. Indeed, they are moderated by several factors, such as country familiarity, product category, involvement, public/private consumption, and social visibility, among others.

The CI literature seems to have followed two seemingly different paths: one using CI as a means to assess the international acceptability of a country's products and the other assessing CI from a tourism perspective as a possible destination. Each stream focuses on different aspects of CI depending on the relevance of each CI aspect to the targeted groups 
(e.g., consumers, tourists). Although these two streams of research have developed independently of each other and are disseminated in different academic journals and conferences, they are interrelated. Recent empirical evidence (e.g., Nadeau et al. 2008; Lee and Lockshin 2011; Bowe et al. 2013) suggests that CI and destination image are interrelated and that the image of a country as a tourist destination spills over to the evaluation of local products. Ryu, Decosta and Andéhn (2016) find that a reverse effect is also in place and that the evaluation of local products influences the image of a country as a destination. Regardless of the image distinctions identified and the paths, little empirical work exists on how CI is formed. Bar-Tal (1997) produces a process model that explains how several factors contribute to the development of CI. The conceptual model focuses on the perceiver's background and relationship with the people from the evaluated country, the transmitting mechanism (e.g., media, direct contact), and the facilitators and inhibitors of the information transmission process. However, the focus is on the process, and little attention is paid to the content and source of information that help shape CI.

CI refers to "the total of all descriptive, inferential, and informational beliefs about a particular country" (Martin and Eroglou, 1993, p. 93) and is conceptualized as attitudes towards the country. The CI definition is generic and does not particularly aim at the products of a country. Roth and Romeo's (1992) study shows that there is a link between consumers' evaluations of a country's products (i.e., product-related CI) and perceptions of the country's culture, economy and politics (i.e., general CI). Consumer's attitudes toward the product of a country are related to the match between the product and country. Papadopoulos and Heslop (1993) advocate the use of the term product CI for this type of CI. According to them, the object of a product CI is a product category from a country, which can be seen as a subsidiary component of a country's general image. The distinction of CI into general (also referred as macro CI by some academics) and product-related CI (also referred as micro CI) has persisted 
in the current literature (see Pappu et al., 2007; Magnusson et al. 2014, Balabanis and Diamantopoulos 2004; Jaffe and Nebenzahl 2001, 2006; Nebenzahl, Jaffe, and Lampert 1997; Tseng and Balabanis 2011; Usunier and Cestre 2007). Product-related CI is context-specific and structured around the country's industry competences according to the patterns of global production specialization (Papadopoulos 1993). General CI captures a broader spectrum of country-related factors and associations than the product-related CI. Mossberg and Kleppe (2005) graphically depicted a hierarchical relationship between the two dimensions of CI and explained that general "country image can be perceived as a generic pool of associations, which is not linked to any particular context" (p.497), whereas "the image unit or object related to a product $\mathrm{CI}$ is a product class from a specific country, which can be perceived as a sub-unit of a country's general image" (p.496). Given the differences between the two dimensions of CI in terms of scope and origins, a discriminating approach is required when studying them.

\section{Influence of brands and products on industry image and CI}

Despite an increasing acknowledgment of the influence of brands and products on CI (Maheswaran and Chen 2009), surprisingly little empirical research has assessed these effects (e.g., Kim, 1995; Kim and Chung 1997; White 2012; Magnusson et al. 2014; Lee et al. 2016). Using market data for 13 brands in a single industry (i.e., subcompact cars) from the United States and Japan from 1982 to 1987, Kim (1995) and Kim and Chung (1997) find that the popularity of a set of car brands has a positive effect on the image of the Japanese car industry in the United States. Their analyses show that six Japanese car brands collectively created unique images for themselves, reflected the image of the whole Japanese car industry, and were beneficial for other car brands from Japan. Kim and Chung (1997) find that the positive image of foreign brands transfers to the image of the whole industry of their COO. 
White's (2012) study is not based on any theoretical arguments. She empirically examines the effects of three brands (Skype, IKEA, and Red Bull) on the image of their respective COOs (Estonia, Sweden, and Austria) using pre- and post-test comparisons in a U.S. sample. The treatment was exposure to a four-minute video that revealed to respondents the real $\mathrm{COO}$ of the three stimuli brands. She finds that the minority of respondents who, in the pretest, knew the real origins of the brands scored the CI higher than those who did not. Brand image was positively related to CI, and the treatment (knowledge of the brands' COO) had a positive effect on the respective CIs. The effect was strongest for Estonia (for the Skype brand).

Two subsequent studies (Lee et al. 2016; Magnusson et al. 2014) use memory schema theory to explain the reverse $\mathrm{COO}$ effect. Both studies' theoretical justification of the effect is based on associations with the country that consumers store in their memory and then use to evaluate CI, though the approaches in each study differ. Magnusson et al. (2014) conduct an experiment on how fictional brand transgressions (product recalls of a car) of three prototypical German and South Korean brands affect the micro image of the respective COO. They confirm that brand transgression has a negative effect on micro CI. The main assumption is that prototypical brands of a country have the potential to influence micro CI. Prototypical brands, according to Magnusson et al. (2014), are dominant and iconic brands. Conversely, Lee et al. (2016) find that the general CI of an advanced country (Australia) is influenced by product categories that are congruent with the country but not by product categories that are incongruent. They define congruence as the extent to which a product category's associations share content and meaning with the country's associations. Australian wine served as the congruent product, and Australian laptops served as the incongruent product. However, evidence of a causal direction is weak, as the researchers test their hypothesis using a cross-sectional research design. Furthermore, the selected sample was 
unfamiliar with Australia (the country whose image they assessed), and therefore memory schema about the country was underdeveloped. The associative nodes of wine or laptops with Australia were weak or nonexistent.

\section{Memory schema theory}

Memory schema theory and the attitude formation literature provide the theoretical framework for understanding CI development and change. Hastie and Park (1986) address the relationship between information stored in memory (schema) and CI evaluations. Specifically, they identify two types of judgment tasks -memory-based and online- and outline three possible types of information-processing models related to the causal priorities of memory schema or judgment: (1) no priority-independence (i.e., no relationship between the two), (2) judgment causes memory schema (i.e., biased retrieval, biased encoding, and incongruitybiased encoding), and (3) memory schema causes judgment (i.e., availability-biased judgment based on the availability heuristic theory). Their research is important for understanding how information about a country collected or accessed by consumers (intentionally or unintentionally) and stored in memory (as a network of associations) influences the consumers' judgments about the country, and therefore their work helps disentangle the puzzle of causal direction. According to Hastie and Park (1986), in many cases, such judgments are memory based, and people inevitably rely on information or evidence stored in their long-term memories (their associative networks or schemas) to make an evaluation. Consequently, a relationship between information stored in memory and judgment can be established by focusing on memory-based process tasks. This can be accomplished by inducing individuals to retrieve information from their memories, which can then serve as input in their judgments (Hastie and Park 1986).

The second type of judgment task that Hastie and Park (1986) identify is online 
judgment. In this process, information input about an object is external to the individual (i.e., it is not stored in his or her memory), and input moves into working memory in the form of a judgment. This type of judgment formation is called "online" because the person forms a judgment as he or she encounters information. In online processes, whether it is the judgment that causes memory or whether the two (memory and judgment) are independent of each other is difficult to predict (Hastie and Park 1986). In their experiments, Hastie and Park (1986) provide empirical evidence that memory-based judgments are stronger than judgments originating from online processes (judgment-causes-memory and independence theories). Their results confirm that memory is not independent of the judgments formed and that memory causes judgment.

In online tasks described above, judgments of the objects are made in an automatic and nonconscious manner as respondents spontaneously evaluate the objects; this nonconscious evidence is more prominent if research is conducted under conditions that resemble the real world outside of the laboratory (Bargh, 2002). However, in line with the above studies, the focus of this study is on explicit measurements of the CI (through selfreporting rating) which is the outcome variable. It does not consider nonconscious cognitive processes (Bargh, 2002) which can be manifested only with the use of an implicit measure of CI. Implicit here refers "to a measure of which people are unaware, or to a basis of the attitude of which people are unaware, or to an effect of an attitude of which people are unaware" (Petty et al., 2007, p.658). This is not a problem as implicit and explicit measures are postulated to be relatively independent of each other and to operate in different situations. The two measures are not expected to be in discord (Petty et al., 2007, 2019). 


\section{General CI and product-related CI}

Drawing on the aforementioned theories, we can check the causal relationship between a country's brands and CI by analyzing the brand cues stored in memory. Specifically, a memory-based experimental procedure can compare CIs derived from memory with those derived from an online process. If memory-based CIs are different from online CIs, we can conclude that the person is using the information retrieved from his or her memory schema to form the CI. If the resulting CIs are the same in the two processes, we can infer that the person is not using retrieved information about a country's brands to assess the CI.

To establish the causal relationship between CI and the brands of a country, we experiment with the brand information stored in and retrieved from memory. With this approach, we (1) establish that we are testing the effect of brands that form part of individual consumers' memory schemas about the country rather than preselected brands that may not be part of their schemas and (2) ensure that the country's memory schema is activated (through the recall task) rather than assuming automatic activation and the use of consumers' schema in CI evaluations. To be consistent with previous research (e.g., Magnusson et al. 2014; Pappu et al. 2007), we use two dimensions of CI: product-related (or micro) and general (or macro) CI. According to Heslop and Papadopoulos (1993) and Pappu et al. (2007), productrelated CI and general CI are conceived as two interrelated dimensions of CI. The productrelated CI dimension is related to the products of a country. The general CI dimension is related to the general aspects of a country, such as its economy and political organization.

Pappu et al. (2007) note that prior research has relied on one or the other dimension and that the inclusion of both can provide a more accurate evaluation of CI. From a practical perspective, the use of product-related and general CI dimensions is beneficial for another reason. Fazio (1995, p. 262) suggests that the functionality of an attitude depends on "the extent to which the attitude is capable of being activated automatically from memory when 
the individual observes the attitude object." The accessibility of attitudes is important for their activation potential and their functionality (e.g., usefulness to guide judgment and make decisions). Because general and product-related dimensions of CI represent different aspects of an attitude toward a country, they should have different levels of accessibility. The strength of the respective CI is related to the knowledge base from which product-related and general CIs are formed (Fazio, 1995). For example, White (2012) finds that respondents were more familiar with the products of a country than with the country itself. However, less consumerist-minded people may not know more about the products of a country than its people and culture. Although the conditions of White's (2012) study may not apply universally, it raises the issue of differences in the knowledge sources people draw on when forming product-related and general CIs. Because product-related and general CIs are interrelated (Heslop and Papadopoulos,1993; Pappu et al. 2007), their relationships with third variables are expected to be related and in the same direction. The hypothesized effects of third variables on product-related and general CIs will be parallel and will be expressed as such. However, because product-related CI draws more from an individual's knowledge of the brands of a country, we expect (though do not formally express here) that product-related CI will be more strongly affected by information about brands than general CI. Thus, we propose the following:

$$
\begin{aligned}
& H 1 \text {. Information about a country's brands retrieved from memory influences (a) } \\
& \text { product-related CI and (b) general CI. }
\end{aligned}
$$

The valence of the retrieved information affects the direction of the relationship proposed in H1, as indicated by the expectancy-value model (Ajzen 2001). Favourability (valence) of brand associations and its impact is a well-researched topic in the brand management and image transfer literature (Keller, 1993; Dacin and Smith 1994; Riezebos,2003 and Story 2005). According to that stream of literature, favorable associations lead to positive 
attitudes towards a brand. Similarly, Krishnan (1996) concludes that brands with strong images have more positive than negative memory associations (i.e., net positive memory associations). Consistent with the above arguments, Hastie and Park (1986) propose that the effect of information retrieved from memory on judgments depends on the balance between favorable and unfavorable items recalled. They use a recall ratio to conceptualize the balance or imbalance of favorable to unfavorable items retrieved from memory (the recall ratio is calculated by dividing the number of favorable items recalled by the total number of items recalled, which include favorable, unfavorable, and neutral items; it is indicated as a proportion to account for differences in the number of items recalled). A similar approach was used by Maheswaran (1994) to assess the effects of favorable and unfavorable thoughts about a country on country evaluations.

More recently, the meta-cognitive model of attitudes (Petty et al. 2007) suggests that individuals may store in their memory evaluative associations of both positive and negative valence about an attitude object like a country. According to this approach, participants are required to tag their associations as positive or negative, true or false. The term meta-cognition concerns an individual's thoughts about his/her thoughts. In the present study, a meta-cognitive approach is used by asking individuals to tag brands as favorable or unfavorable after elicitating brands associated with the country. According to that theory, the attitude object evaluations are expected to be valence-congruent with elicited associations (e.g., the evaluated country). Petty et al. (2007, 2019) and De Liver et al. (2007) suggest that a person develops an ambivalent attitude about an object when, being equally accessible, positive and negative associations are present. They propose that attitudinal ambivalence about an object (when equally strong positive and negative associations are present) will be recorded as "a neutral or slightly positive attitude that represents the integration of the separate positive and negative reactions" (Petty et al., 2007, p.668). Hence, we expect that if the valence ratio is closer to 1 more favorable brands 
will be elicited and more positive the evaluations of CI. A valence ratio closer to .5 will indicate ambivalence about the CI (nearly equal number of favorably and unfavorably rated brands) and a neutral or slightly positive evaluation is expected in the rating scale. If the valence ratio is near to 0 , unfavorably rated brands are more salient in the individual's memory and a weak rating of the $\mathrm{CI}$ is expected.

Thus:

$H 2$. The valence ratio of a country's brands retrieved from memory positively influences (a) product-related CI and (b) general CI.

\section{Industry image}

The operationalization of CI is inconsistent across studies, which makes comparison difficult. For example, Han (1989), one of the first researchers to examine the nature of CI effects, equates CI with industry image, creating some misapprehension in subsequent studies. According to Han (1989, p. 225), "Country image and brand attitude are assessed with subjects' overall evaluation of products made in the country (e.g., Japanese television sets) and brands from the country (e.g., Panasonic television sets)." Clarifying the levels according to which CI is evaluated is important for assessing any possible spillover image effects from one industry to another (Magnusson et al. 2014) or image transfer to other superordinate or subordinate levels (e.g., product-related and general country level) of CI (Pappu et al. 2007).

Dowling (1993) and Magnusson et al. (2014) acknowledge the influence of brands on the image of the industry to which they belong. Dowling's $(1994,2001)$ conceptualization of image includes four components linked to one another through two-way arrows, indicating an interaction between each pair: CI, industry image, company image, and brand image. We consider the previous argument and examine industry image as a related but separate entity from CI. As such, we propose that the industry image of a country is influenced by the brands of that industry retrieved from memory and whether they are positively or negatively 
evaluated. For the reasons explained in the discussion of $\mathrm{H} 2$, the valence ratio will be used here as an independent variable to check the balance of positively and negatively rated brands. Thus:

H3. Information about a country's brands retrieved from memory influences the corresponding industry image.

H4. The valence ratio of the retrieved brands from the evaluated industry of a country positively influences the corresponding industry image.

\section{Products of a country}

In addition to brands, consumers associate countries with specific product categories (Balabanis and Diamantopoulos 2004; Andéhn and L’Espoir Decosta 2016; Jaffe and Nebenzahl 2001, 2006; Nebenzahl et al. 1997; Tseng and Balabanis 2011; Usunier and Cestre 2007). This argument builds on the economic theories of comparative advantage and international trade specialization, which maintain that certain countries have an advantage over other countries because of factor endowments that affect the opportunity cost in the production of certain products (Maneschi 1998). According to the theory on international trade specialization, consumers are able to associate countries with certain products and their superior ability to produce such products. For example, Switzerland is world-renowned for its chocolates, Belgium for its beers, and Iran for its carpets. Previous studies have used different lenses to examine this phenomenon. For example, Magnusson et al. (2014) rely on prototype theory and explain that the effect of brands on CI occurs only with prototypical products or brands. Lee et al. (2016) argue that the same effect occurs only with products that are congruent with the country. This argument is in line with their previous study (i.e., Lee and Lockshin 2012), which highlights the congruence between the product category and the destination image. According to schema theory and Tversky and Kahneman's (1973) 
availability heuristic, salience and accessibility of information are key influencers of judgment. In line with these arguments, in memory-based processes, we expect consumers to base their evaluations of CI on salient products that they can retrieve from memory. Thus: H5. Information about a country's products retrieved from memory influences (a) product-related CI and (b) general CI.

H6. Information about a country's products retrieved from memory influences the corresponding industry image.

\section{Hierarchy}

Categorization theory (Rosch et al. 1976) postulates that people structure the categories of different entities into hierarchies by breaking down larger categories into smaller ones and that the amount of information transfer from superordinate categories to basic categories decreases. In our case, consumers can categorize different products according to their $\mathrm{COO}$, their industry membership, and the brands to which they belong. Rosch et al. (1976) suggest that information about members of a subordinate category (e.g., brands assigned a specific industry) is more concrete and imaginable because these members share more attributes with one another than with members of a superordinate category (e.g., brands of a specific COO). The number of attributes increases when moving to the superordinate category (Goldberg 1986) because superordinate categories tend to include more diverse exemplars. Applying this argument to our context, we expect that more attributes exist at the country level than at the industry level. As such, we assume that as people move from subordinate categories (e.g., the brand category) to less coherent superordinate categories (e.g., the country category), image evaluations based on the availability of brand information in memory become less direct and, therefore, weaker. 
$H 7$. The effect of recalled brands on the corresponding industry image is stronger than the corresponding effect on CI.

H8. The effect of recalled brands on $\mathrm{CI}$ is weaker than the effect of the pertinent industries' image on CI.

The final hypothesized relationship is proposed by Magnuson et al. (2014) and replicated here to control for possible confounding effects, in line with Becker et al.'s (2016) recommendations. According to Magnuson et al. (2014), the effects of brands on general CI will differ between the image of economically advanced countries and that of newly industrialized countries (NICs). On average, consumers (at least those in the West) are more familiar with economically advanced countries than with NICs (Pappu and Quester 2010). According to this argument, they tend to develop a stronger (Fazio and Zanna, 1981) and more stable, refined, and complete cognitive structure of country knowledge (Alba and Hutchinson, 1987) for advanced countries. On the contrary, consumers' cognitive structures for countries they are less knowledgeable about are weaker and more malleable, and they rely on fewer applicable activated knowledge units to form a CI (Wilson et al. 1989; Wilson et al. 1993). Consequently, consumers' memory structure for NICs is less developed and more likely to be changed and influenced by brands. Magnuson et al. $(2014$, p. 26) argue that the brands of NICs “are more closely associated with the country's general CI in consumers' minds" because the general CI of NICs is composed of a limited number of nodes that are less established in consumers' minds. We do not expect this difference in effect to hold for product-related CI, because product-related CI refers to perceptions at the product level and, in line with the conversion model, information about a country's brands will influence product-related CI regardless of the level of economic development of the country (Magnuson et al. 2014). Thus, we propose the following: 
H9. The effect of recalled brands on the general CI of NICs is stronger than that on the general CI of economically advanced countries.

Figure 1 shows the hypothesized relationships.

Figure 1 goes about here

\section{Overview of studies}

We conducted three experimental studies to test the hypotheses, one pertaining to the effect of brands on CI (Study 1), a second pertaining to the effect of products on CI (Study 2), and a third pertaining to the effects of brands and products on industry image (Study 3). We used an experimental approach to overcome the weaknesses of cross-sectional surveys commonly used in CI studies to detect the direction of the observed effects (Lee et al. 2016). Furthermore, we allowed consumers from a British sample to determine the brands and products associated with a country rather than using a prespecified set of brands and products. The evidence that Kim (1995), Kim and Chung (1997), and Magnusson et al. (2014) provide is based on two industries (car and beer) that did not emerge naturally but were selected on the basis of the different rationales and assumptions underlying their studies (e.g., data availability, prototypicality of the stimuli brands). Their approach constrains generalization of the effects to other industries that may also affect CI. Furthermore, the use of brand transgressions (product recall or contamination) to check changes in CI may suffer from negative bias (see Ajzen 2001). When negative cues are used to test the impact on attitudes, the effects are usually higher than normal (Ajzen 2001). As in the case of Magnusson et al.'s (2014) study, we need to test whether the observed effects of brands on CI are inflated from the use of transgressions. 
To test our hypotheses, we selected two COOs namely, Italy and South Korea. There are several reasons that underlie their choice for this study. First, H9 refers to the moderating effect of the level of economic development of the $\mathrm{COO}$ on the influence of the recall brands on the general CI thus, a NIC and an advanced economy country are needed to test the effect. Second, to be consistent with Magnusson et al. (2014), we used the same NIC country (South Korea) in our study. Magnusson et al. (2014, p. 27) argue that in consumers' minds, South Korea's “image is still far less developed than that of advanced economies (Anholt 2010; Magnusson et al. 2011), and several business publications still categorize it as an emerging market (MSCI 2012; Vale Columbia Center 2012).” South Korean products are widely available in the United Kingdom and largely known to British consumers. Third, for the advanced economy country, we used Italy, as there is sufficient diffusion of Italian brands and/or products in the United Kingdom. South Korea has a weaker CI than Italy, and in general British people know less about South Korea than Italy.

\section{Sample composition}

For the three studies, we used data from an online panel of British people. Data from such panels offer an acceptable sampling frame for testing relationships among variables (Baker et al. 2010; Callegaro et al. 2014). To avoid any confounding effects (the influence of respondent's origin on both the dependent variable and independent variable), respondents were screened to be of non-Italian and non-South Korean origin. All respondents were also screened to be 18 years of age and older.

We collected an aggregate of 558 valid responses from the three studies Of the respondents, 52\% were men, and ages ranged from 19 to 69 years, with an average age of 40.76 years $(\mathrm{SD}=11.79)$. The median annual income was in the band of $£ 40 \mathrm{~K}$ to $£ 50 \mathrm{~K}$. Table 1 shows the distribution of the reported incomes of the sample. There were no 
demographic differences across the groups used in the studies (gender: $\chi^{2}=3.780$, d.f. $=4, p$ $=.437$; age: $\mathrm{F}(4,553)=1.271, p=.280$; income: $\mathrm{F}(4,552)=1.704, p=.148)$. A breakdown of the sample per experimental group is provided in each study separately.

Table 1 goes about here

\section{Measures}

We used existing scales to operationalize the image and control variables. To measure CI, we differentiated two components: general and product-related. We measured general CI with Pappu, Quester, and Cooksey's (2007) nine-item, seven-point semantic differential scale. We assessed product-related CI with a seven-item, seven-point Likert scale adapted from Klein, Ettenson, and Morris (1998). Respondents evaluated industry image on a four-item, sevenpoint Likert scale: "The industry is competitive internationally," "The products/services of that industry are prestigious/of high status," "The products/services of that industry are of high quality," and “The products/services of that industry are up-market.” In line with Oberecker and Diamantopoulos (2011), we measured consumer ethnocentrism with a fiveitem, seven-point Likert scale adapted from Shimp and Sharma's (1987) CETSCALE. We measured country familiarity with a two-item, seven-point rating scale ("How familiar do you consider yourself with country X?" and "How knowledgeable do you consider that you are of country X?”). Finally, we measured brand/product favorability (for each brand/product recalled) with a one-item, seven-point rating scale. All scales used in the study are reflective. For the purposes of this study, we included only the Italian and South Korean brands the respondents mentioned in the analysis. 


\section{Measurement model validation}

Using the pooled data from Studies 1 and 2, we validated the CI constructs through confirmatory factor analysis; specifically, we examined convergent and discriminant validity. The analysis of the measurement model included the scales of general CI and product-related CI of Italy and South Korea, consumer ethnocentrism, and country familiarity. The first general CI dimension involved the economic/technological aspects of the country, and the second dimension entailed political aspects. The fit of the measurement model was adequate $\left(\chi^{2}(524)=1053.480, p<.001, \chi^{2} /\right.$ d.f. $=2.010 ;$ comparative fit index $[\mathrm{CFI}]=.933 ;$ root mean square error of approximation $[\mathrm{RMSEA}]=.054$; standardized root mean square residual $[\mathrm{SRMR}]=.048)$.

We calculated the fit statistics for the industry image measurement models of the two countries separately (Study 3 did not involve measurements of CI). For the Italian industries' image measurement model, the fit statistics were $\chi^{2}(260)=369.528, p<.001, \chi^{2} /$ d.f. $=1.421$; $\mathrm{CFI}=.954 ; \mathrm{RMSEA}=.063 ;$ and $\mathrm{SRMR}=.064$. The model included the images of processed food, fashion, and automobile industries together with the control variables. For the South Korean industries' image measurement model, the fit statistics were $\chi^{2}(125)=217.325, p<$ $.001, \chi^{2} /$ d.f. $=1.739 ; \mathrm{CFI}=.937 ; \mathrm{RMSEA}=.083 ;$ and $\mathrm{SRMR}=.060$. This model included measurements of the Korean electronics and automobile industries in addition to the control variables.

\section{Common method variance (CMV)}

We tested for CMV using the confirmatory factor analysis marker technique, which is considered superior to other methods of CMV detection. We followed Williams, Hartman, and Cavazotte's (2010) procedure. As a marker, we used three items from Hepler and 
Albarracin's (2013) dispositional attitude inventory ("How do you feel about [a] cold showers, [b] public speaking, and [c] taxes?") on a seven-point rating scale. A comparison of the fit statistics of the baseline model, U model, I model, and C model through a chi-square test showed that the I model should be retained. The I model is partially noncongeneric and assumes that the marker construct will have an equal effect on the items of each substantive construct but different effects on each construct. The I model's fit was $\chi^{2}(625)=1172.131, p$ $<.001$. We generated the R model by constraining the retained model's (I model's) covariates to the values derived from the baseline model. The baseline model constrains the effects of the marker construct to the substantive construct to zero. The R model's fit was $\chi^{2}(660)=$ $1208.868, p<.001$. The chi-square difference test $\left(\Delta \chi^{2}(35)=36.737, p=.388\right)$ shows that the $\mathrm{R}$ model is not worse than the I model, which indicates that CMV does not affect the substantive relationships.

\section{Types of analysis}

We used linear mixed models to test the hypotheses regarding the differences between memory-based evaluations of CI and online evaluations of CI (H1, H5, and H9). We preferred this model to an analysis of covariance (ANCOVA) because one of the covariates (country familiarity) was related to the main effect (COO effect) of the study, thus violating the condition of covariate independence required for an ANCOVA. We used an ANCOVA to test the hypotheses regarding the differences between the memory-based development of industry image and the online development of industry image (H3 and H6). We conducted size effects analysis to compare the brand effects on CI with the brand effects on industry image (H7) and the brand effects on CI with the industry effects on CI (H8). Finally, we used hierarchical linear regression analysis to test the influence of valence on memory-based CI development (H2) and memory-based industry image development (H4). Table 2 
summarizes the hypothesized paths and the results.

Table 2 goes about here

\section{Study 1: the effect of brands on CI}

\section{Method}

In Study 1, we used a mixed effects $(2 \times 2)$ experimental design to test the effects of brands on $\mathrm{CI}$ (as postulated in $\mathrm{H} 1, \mathrm{H} 2$, and H9). The between-subjects factor was the type of CI measurement process employed (memory-based vs. online), and the within-subject factor was the COO effect (advanced country vs. NIC).

We randomly allocated respondents to two groups (memory-based CI development process and online CI development process). The memory-based CI development process group had to recall as many brands as they could from the stimulus country. Then, respondents, through the use of a piped text procedure (available via the online platform), were prompted to assess the favorability of each brand they recalled on a seven-point favorability scale. The second section of the study captured respondents' image of the industry corresponding to each of the brands recalled. The third section measured the CI of the stimulus country. Data collection software allowed us to randomize the order of the second section and the third section. The final section assessed respondents' familiarity with the country, consumer ethnocentrism, and demographics (gender, age, and income). This experimental group consisted of 115 respondents of which 53\% were male. The average age was 39.24 years ( $\operatorname{std} d e v=11.83)$. The median income was in the $£ 40 \mathrm{~K}-£ 50 \mathrm{~K}$ a year income band. The data collection target was 130 complete responses for each experimental group. However, 15 respondents failed the attention filters and were excluded from the analysis Respondents in the online CI development process group were asked to rate the CI of the stimulus country followed by the control variables (familiarity, consumer ethnocentrism, 
and demographics). The experimental group in the online measurement condition consisted of 112 respondents, of which $50.9 \%$ were male. The average age was 39.60 years (std $\mathrm{dev}=12.24)$. The median income was in the $£ 30 \mathrm{~K}-£ 40 \mathrm{~K}$ a year income band. Eighteen respondents failed the attention filters and were excluded from the analysis.

The within-subject factor included the assessment of an advanced economy and a NIC. As the NIC stimulus, we selected South Korea, as explained before. As H9 implies, the moderating effect of the level of economic development of the stimulus country needs to be controlled (Magnusson et al. 2014).

Both groups (i.e., memory-based and online CI development process) needed to repeat the same process for both countries. Data collection software allowed us to alter the order in which each country served as a stimulus. To avoid contamination between the countries, we separated the two stages with a distraction task. Before continuing to fill out the appropriate sections related to the second country, respondents read a short newspaper article about the recent budget in the United Kingdom and rated their approval on a three-item Likert scale.

After we removed careless respondents, 115 (for the memory-based CI development process group) and 112 (for the online CI development process group) usable responses remained. We removed careless respondents with the use of attention filters, which are common in online surveys (see Meade and Craig 2012).

Control variables. Following the advice of Becker et al. (2016), we selected the control variables theoretically. First, we controlled for COO effects. This well-established effect in the literature is based on categorical cognition (see Verlegh and Steenkamp's [1999] meta-analysis). In general, this body of research suggests that advanced economies enjoy more favorable evaluations than NICs. To control for the confounding effects of such country differences on CI ratings, we included the assessed country stimuli as a control variable. In addition to the direct effect of country stimuli on CI, the country moderates the effect of 
brands on CI (see Magnusson et al. 2014). To control for this effect, we included the interaction between country stimuli and CI development process as a control variable.

A person's familiarity with a country affects not only the way he or she perceives the country (Lee and Ganesh 1999; Samiee et al. 2005) but also the way he or she forms CIs (Han 1989). This notion is theoretically congruent with the premises of Allport's (1954) contact theory and mere exposure theory, which have been widely supported in empirical research (Pettigrew and Tropp 2006). Mere exposure and contact theories suggest that, all else being equal, the greater individuals' contact and familiarity with other groups, the more positive are their evaluations of those groups. More recently, Lee et al. (2016), following Han's (1989) arguments, identified a moderating role of country familiarity. They hypothesize that country familiarity decreases the influence of products on CI. The theoretical argument is that people who are familiar with a country use multiple sources of information to form their image of that country rather than just the products of the country that managed to make it to international markets and break through the informational clutter and into the minds of consumers. However, Lee et al.'s (2016) empirical results lend only marginal support to the theory.

Thus, we use familiarity with each of the stimulus countries as a control variable. We include the two types of the proposed relationships between country familiarity and CI (direct effect and moderating effect) in the analysis. Because familiarity varies by stimulus country, we nested familiarity within the stimulus country in our model.

Theoretically, consumer ethnocentrism is negatively related to CI evaluations of foreign countries (Shimp and Sharma 1987), with many studies finding empirical support for this effect (e.g., Roth and Diamantopoulos 2009). To eliminate the effect of individual differences in consumer ethnocentrism, we included it as a control variable. 
Finally, we used three demographic variables (gender, age, and income) as control variables. Products or brands associated with a country may be more appealing to men (e.g., motorcycles), younger people (e.g., fashion products), or people with high incomes (e.g., premium/luxury products). Furthermore, the composition of products commonly associated with each country may vary in appeal to each demographic group.

$C M V$. To check for $\mathrm{CMV}$, we asked respondents to provide ratings on a marker variable. As explained earlier, we used three items from Hepler and Albarracin's (2013) dispositional attitude inventory as a marker variable.

Results

Brand $\rightarrow C I$ (H1 and H9). In this subsection, we test H1, which predicts a statistically significant difference in CI between the memory-based CI development process and the online CI development process, using a linear mixed-effects model. The control variables serve as covariates, and the assessed country stimuli also serve as a moderator (e.g., advanced economy vs. NIC), as theoretically specified. We tested the hypothesized effects on the different dimensions of CI with the restricted maximum likelihood method and the fixedeffects model. We used type III sum of squares to calculate the effects in the models. Table 3 reports the results for all CI dimensions. The results confirm significant differences in the effects of the CI development process on product-related CI and general CI (economic/technological) dimensions. We identified no effects for the political aspects of general CI. An examination of the estimates of the effect indicated that the CI dimensions have higher values in the memory-based CI development process than in the online CI development process. These results provide support for $\mathrm{H} 1$; activated information about the brands of the country stored in respondents' memories influences their CI evaluations. 
H9 postulates that the effects of brands on general CI will differ between the image of economically advanced countries and that of NICs. As explained in the justification of the hypotheses, we do not expect this difference to hold for product-related CI. An examination of the shows the existence of $\mathrm{COO}$ effects for the two general CI dimensions. We find that the CI development process effects on product-related CI varied across the two countries $(\mathrm{F}(1$, $334.219)=7.815, p=.005)$. The results suggest that when respondents recall the brands of each country, there are no statistical differences in the product-related CI of the two countries. However, in the online development process, the product-related CI for the economically advanced country was higher than that of the NIC. These results provide no support for H9, because we identified no significant interaction between the general CI development process and the country stimuli. Instead, the results confirm that the brands of a country have an equally beneficial effect on the general CI of both the advanced economy and the NIC. However, brands' effects are stronger on the product-related CI of the NIC than on the product-related CI of the advanced economy. In this study, the NIC had weaker general CIs (in both dimensions) than the economically advanced economy, but not weaker productrelated CIs.

Table 3 goes about here

Memory-based evaluations of CI: valence (H2). Maheswaran (1994) examines the link between familiarity and the number of thoughts generated about a country. His findings indicate that the number and valence of thoughts vary by the country stimulus and level of familiarity. In the current study, a paired t-test analysis reveals that the average number of brands recalled and the valence ratio of the brands (favorably rated brands to total brands) were higher for the advanced economy (Italy) than for the NIC (South Korea), with t-values $($ d.f. $=114)$ equal to $7.567(p<.001)$ and $3.187(p=.002)$, respectively. Similarly, as we 
expected, the product-related CI and general CI (political) of the advanced economy were higher than those of the NIC $(\mathrm{t}=2.999, p=.003$ vs. $\mathrm{t}=4.844, p<.001)$. We observed no significant differences $(\mathrm{t}=.860, p=.392)$ in the general CI (economic/technological). An examination of the relationship between country familiarity with the brands recalled and the valence ratio of the recalled brands of the advanced economy and the NIC, respectively, indicated no statistical significance (correlation coefficients $=.111, .095, .082, .115 ; p>.1$ ). In addition, Maheswaran (1994) suggests that familiarity interacts with the use of COO cues in consumers' evaluations of products. Although his study focuses on COO effects while we focus on the reverse COO effect, it is reasonable to assume that the brand information stored in consumers' memories has a different impact on people who are familiar with the country than those who are unfamiliar with it. As such, we include the interaction terms of country familiarity $\times$ number of country brands recalled and country familiarity $\times$ valence ratio of country brands recalled as control variables. To test the effects postulated in $\mathrm{H} 2$, and taking into account the two aforementioned interaction effects as control variables, we used Hayes's (2012) moderated regression model. We mean-centered the variables and used bootstrapped, heteroskedasticity-consistent standard error estimations. The dependent variables were the different dimensions of CI, while the independent variables included the ratio of favorably rated brands to total brands recalled from a country, plus the control variables.

$\mathrm{H} 2$ postulates that $\mathrm{CI}$ dimensions are positively related to the ratio of the number of positively rated brands to the total number of brands recalled from a country. As Table 4 and Table 5 show, the results confirm $\mathrm{H} 2$ with respect to the product-related CI for both Italy and South Korea. However, the ratio had no effect on either of the two dimensions of the general CI of Italy and had a positive effect on only one dimension of the general CI (economic/technological) of South Korea. Thus, the results provide partial support for H2. 
Table 4 and Table 5 go about here

\section{Study 2: the effect of products on CI}

\section{Method}

Study 2 examines the effects of a country's products that consumers store in memory on CI (as postulated in H5). The study follows the same memory-based CI development process as in Study 1. We used a mixed-effects $(2 \times 2)$ experimental design, the betweensubjects factor was the type of CI measurement process employed (memory-based vs. online), and the within-subject factor was the COO effect (advanced country vs. NIC). Respondents were asked to recall as many products as they could from the stimulus country. We collected additional measures for the control variables and CMV marker variable, employing an identical procedure to that in Study 1. After removing respondents who failed the attention filter questions, as explained in Study 1, there were 116 usable responses in the memorybased experimental group. $46 \%$ of the respondents were male and the average age was 41.84 years ( $\operatorname{std} \mathrm{dev}=12.40)$. The median income was in the $£ 30 \mathrm{~K}$ to $£ 40 \mathrm{~K}$ income band. Fourteen respondents were excluded from the analysis as they failed the attention filters. The online condition experimental group was the same as in study 1 (112 respondents, 50.9\% male, average age $=39.60$ years with an std dev of 12.24 years and median income in the $£ 30 \mathrm{~K}$ $£ 40 \mathrm{~K}$ band).

Results

Product $\rightarrow$ CI (H5). This section tests H5. Table 6 reports the results of a linear mixed-effects model used to assess differences in CIs when the memory-based CI development process involves recalling products from a stimulus country. We used the same analytical procedures 
as in Study 1 here. The results provide empirical support for H5, which proposes a difference between the memory-based and the online CI development processes for all the aspects of general and product-related CI. An examination of the estimates of the effects (not reported here) indicates that CI scores were higher in the memory-based condition for all aspects of CI. The other effects are consistent with, though weaker than, those for the brand-retrieval task reported in Table 3 . We found no interaction effect of the stimulus country and CI development. The results fail to confirm Magnusson et al.'s (2014) results that the products of a country have a different effect on the CI of advanced economies and NICs. It appears that the effects of products are the same on both types of countries' CIs.

Table 6 goes about here

\section{Study 3: the effects of brands and products on industry image}

\section{Method}

Study 3 examines the effects of the brands and products of a country on industry image (as we postulate in $\mathrm{H} 3, \mathrm{H} 4, \mathrm{H} 6, \mathrm{H} 7$, and $\mathrm{H} 8$ ). In the previous studies, respondents evaluated the industry images of the brands (Study 1) or products (Study 2) that they had recalled directly through the piped text procedure in the survey software. If respondents identified more than one brand or product from the same industry, we used the average scores of each industry per respondent. After the completion of Studies 1 and 2, we identified the corresponding industries of the recalled brands and products. We first identified all the industries in the memory-based condition and then classified brands and products into industries using the U.K. Standard Industrial Classification of Economic Activities 2007. At this stage, we identified nine Italian industries and five South Korean industries. However, owing to the sparsity in the cells, we used only the industries that had a sufficient number of observations in the analysis. Consequently, we included three Italian industries (processed food, fashion, 
and automobile) and two South Korean industries (electronics and automobile). For the online evaluation of the resulting industries, we used two subsamples of respondents (those who evaluated the image of the Italian industries and those who evaluated the image of the South Korean industries), due to the large number of measurements and the length of the questionnaire. In addition to industry image variables, the respondents provided their ratings for the control variables and the common method marker variable, using the same procedure as in Study 1. After we removed invalid responses (i.e., respondents who failed to pass the attention filter questions), there were 215 usable responses (108 responses for the Italian industries' image and 107 for the South Korean industries' image). Twenty-two respondents failed the attention filters in the Italian industry image group and 23 respondents in the South Korean industry image group.

For Italy, a $2 \times 3$ experimental design was used. The between-subjects factors are the type of CI measurement process employed (memory-based vs. online) and the type of industry (food, fashion and automobile) measured earlier. For South Korea, a $2 \times 2$ experimental design was used. The between-subjects factors are the type of CI measurement process employed (memory-based vs. online) and the type of industry (electronics and automobile).

The demographics for the online Italian industry image experimental group (108 respondents) were as follows: $59 \%$ of respondents were male; the average age of the sample was 41.72 ( $\operatorname{std} \mathrm{dev}=11.36$ ) and the median income was in the $£ 40$ to $£ 50 \mathrm{~K}$ per year income band. Similarly, the demographics for the online South Korean industry image experimental group (107 respondents) were as follows: $53.3 \%$ of respondents were male; the average age of the sample was 41.47 (std dev=10.92) and the median income was in the $£ 40$ to $£ 50 \mathrm{~K}$ per year income band. The respective memory-based experimental groups were the same as in study 1 for brands (115 respondents, 53\% of the respondents were male; the average age was 
39.24 years with std dev of 11.83 and he median income was in the $£ 40 \mathrm{~K}-£ 50 \mathrm{~K}$ a year income band).

\section{Results}

Brand $\rightarrow$ industry image (H3). We used two subsamples in Study 3 because of the large number of measurements involved in the assessment of the identified industries' images: one to assess the images of the industries of Italy (the advanced economy) and one to assess those of South Korea (the NIC). There were no repeated country observations; thus, there was no need to use the linear mixed-effects model and account for the nested effect of stimulus country familiarity. Instead, we analyzed the data separately for each industry and country with an ANCOVA. The control variables were the same as in the previous analysis, except for the control for stimulus $\mathrm{COO}$ effects. The results reveal significant differences between the memory-based (brands) and online image development processes for the Italian fashion industry image $\left(\mathrm{F}(1,155)=5.874, p=.017, \eta^{2}=.037\right)$ and the Italian automobile industry image $\left(\mathrm{F}(1,171)=14.08, p<.001, \eta^{2}=.076\right)$. There were no statistically significant differences between the memory-based (brands) and online development processes of the Italian processed food industry $\left(\mathrm{F}(1,142)=1.439, p=.232, \eta^{2}=.010\right)$. Similarly, significant differences emerged in the South Korean electronics industry image scores $(F(1,155)=$ $11.386, p<.01, \eta^{2}=.068$ ) but no statistically significant difference for the South Korean automobile industry $\left(\mathrm{F}(1,151)=.006, p=.937, \eta^{2}=.009\right)$. These results provide partial support for H3, as industry images differed in the two image development conditions.

An examination of the marginal means reveals that for all three industries that had a statistically significant main effect, images were higher in the memory-based than the online image development condition. This finding suggests that brands retrieved from memory have a positive effect on certain industry evaluations. An examination of the three Italian 
industries shows that the Italian fashion industry $(\mathrm{M}=5.775, \mathrm{SD}=1.153)$ had a statistically significant and stronger image $(\mathrm{F}(2,236)=18.260, p<.001)$ than both the processed food industry $(\mathrm{M}=5.174, \mathrm{SD}=1.015)$ and the Italian automobile industry $(\mathrm{M}=5.328, \mathrm{SD}=1.193)$. Similarly, the South Korean electronics industry $(M=5.134, S D=1.136)$ had a statistically significant and stronger image $(\mathrm{t}(145)=6.261, p<.001)$ than the South Korean automobile industry $(\mathrm{M}=5.136, \mathrm{SD}=4.579)$. Thus, the memory-based image development process is more beneficial for the industries of the advanced economy country than for those of the NIC.

When checking the interaction of country familiarity with the image development process, we identified two statistically significant effects: one for the Italian automobile industry image $\left(\mathrm{F}(1,171)=9.377, p=.003\right.$, partial $\left.\eta^{2}=.052\right)$ and one for the South Korean electronics industry image $\left(\mathrm{F}(1,155)=4.189, p=.042\right.$, partial $\left.\eta^{2}=.026\right)$. An examination of the interaction plots (see Figure 2 and Figure 3) indicates that the differences in the two image development processes were more pronounced when respondents were less familiar with the respective country. Brands have a stronger effect on the image of an industry of a country for people who have limited knowledge about the country.

Memory-based evaluations of industry image: valence (H4). To test the effects postulated in $\mathrm{H} 4$, we considered the use of the two aforementioned interaction effects as control variables (country familiarity $\times$ number of country brands recalled and country familiarity $\times$ valence ratio of country brands recalled). We again used Hayes’s (2012) moderated regression model. We mean-centered the variables and used the bootstrapped, heteroskedasticity-consistent standard error estimations. The dependent variable was the image of the main industries of the country identified by the respondents. The independent variables included the ratio of favorably rated brands to total brands recalled from a country plus the control variables. 
The regression analysis results provide partial support for $\mathrm{H} 4$, which posits a positive relationship between industry image and the ratio of favorably rated brands to total brands recalled. As Tables 4 and 5 show, the favorability ratio of the recalled brands from the specified countries influences the images of the Italian processed food and fashion industries. This does not apply to the Italian automobile industry and the image of the two salient South Korean industries (electronics and automobiles).

Product $\rightarrow$ industry image (H6). We used an ANCOVA to examine the differences in industry image between the memory-based and the online evaluation conditions, in which respondents in the former condition needed to recall products from each country rather than brands. The results indicated a statistically significant difference between the two evaluation conditions related to the Italian automobile industry $\left(\mathrm{F}(1,145)=9.511, p=.002\right.$, partial $\eta^{2}=$ .062). The relevant differences for the Italian automobile industry were marginally significant (at $p=.1$ ). We found no statistically significant differences in the two South Korean industries. Thus, the study offers partial empirical support for H6, which posits that information about a country's products retrieved from memory affects industry images. This finding applies only to one industry (automobile) of the advanced economy (Italy), suggesting that information about brands stored in memory has a stronger effect on industry image than information about products stored in memory. This may have to do with the limited product variation in an industry and the perfect alignment of an industry with one product category, which may eliminate differences in memory-based and online industry image evaluations. We found no interaction between country familiarity and the type of industry image development process.

Brand $\rightarrow$ industry image versus brand $\rightarrow C I(H 7)$. To test $\mathrm{H} 7$, which proposes that in memory-based image development processes, the effect of recalled brands on the corresponding industry's image is stronger than the effect on the CI evaluation, we compared 
the corresponding size effects (partial $\eta^{2}$ ) from the ANCOVA for the image development processes (memory-based vs. online) on CI and industry image, respectively. We aggregated the partial eta-squared values of the evaluation mode effects using a meta-analytical software package (Comprehensive Meta-Analysis) and transformed the values into Cohen's $d$ effect sizes (see Cohen 1988, p. 276). Accordingly, the average Cohen's $d$ for the effects on the three Italian CI dimensions was .141 and for the South Korean CI dimension was .266. The equivalent average Cohen's $d$ for the three Italian industry images (processed food, fashion, and automobile) was .387 and for the two South Korean industry images (electronics and automobile) was .372 . The z-score values for the three size effects ranged from 2.023 to 4.796 and were all statistically significant $(p<.05)$. To test $\mathrm{H} 7$, we calculated the combined effect sizes for both Italy and South Korea (Cohen's $d=.203$ ) and compared them (using a fixedeffects model) with the combined industry image effect of the industries of both countries (Cohen's $d=.381$ ). Both effects in each subgroup (country and industry image) were homogeneous (overall within Cochran's Q statistic: $\mathrm{Q}(11)=.11 .377, p=.412$ ). Cochran's Q statistic for the differences in the size effects between CI and industry image was statistically significant $(\mathrm{Q}(1)=4.949, p=.026)$. This result confirms H7, as the size effects of retrieved brands on industry image were stronger than the effects on CI.

Brand $\rightarrow$ CI versus industry $\rightarrow C I$ (H8). To test $\mathrm{H} 8$, we followed a similar approach to that for $\mathrm{H} 7 . \mathrm{H} 8$ posits that the effect of the recalled brands on the $\mathrm{CI}$ evaluations is weaker than the effect of the recalled industries. The average Cohen's $d$ size effect for the three dimensions of Italian CI was .244 and for the South Korean CI was .151. The equivalent effects of recalled brands on CI were .140 and .266 , respectively. The average Cohen's $d$ for the evaluation mode effect (for both countries) was .203 when brands from the country were recalled and .197 when products from the country were recalled. Cochran's Q test of the differences between the two size effects was statistically nonsignificant $(\mathrm{Q}(1)=.008, p=$ 
.927). Thus, the results do not provide support for H8. We also performed a similar comparison of the two size effects for each country separately and found statistically nonsignificant results.

\section{Discussion}

The results of this research provide valuable information about issues related to the influence of a country's brands that people store in their memory on the image of the country and its salient industries. First, we find evidence that when consumers are asked to think about the brands of a country, they form a different CI than consumers who form an impromptu image. This effect applies to both an advanced economy and a NIC. Second, we provide evidence of a second type of reverse $\mathrm{COO}$ effect - from products to countries. Third, country familiarity has a positive effect on CI. Fourth, we establish that the reversed COO effect applies beyond the CI to the respective images of salient industries of a given country. Fifth, our findings offer some evidence of the hierarchical nature of the reverse $\mathrm{COO}$ effect moving from brand to industry and from industry to country. Sixth, the effect of recalled brands on CI depends on the valence of those brands. Finally, our study addresses some of the limitations of prior research by allowing consumers to determine which brands and products are associated with a country and adopting an experimental methodology to ascertain the causal direction of the effects.

\section{Theoretical implications}

With the exception of a few theoretical studies (e.g., Bernstein 1984; Dowling 1994, 2001) and four empirical studies (Kim and Chung 1997; Lee et al. 2016; Magnusson et al. 2014; White 2002), scant research has examined the effects of brands on consumers' evaluations of 
a country. Filling this gap is important for both theory and practice. First, this research contributes to international marketing literature by providing additional empirical evidence that reexamines the axiomatic approach to the $\mathrm{COO}$ effect (e.g., that brands can enjoy the reputational benefits of a positive CI). The study shows that certain brands from specific industries influence the way consumers evaluate a country. Prior research on this topic has focused on only one industry (Kim and Chung 1997) or only the negative effects prone to the negativity bias (Magnusson et al. 2014) or has used a cross-sectional design that is unable to detect directionality of effects (Lee et al. 2016), thus forcing consumers to provide responses on preselected brands.

The current research addresses these issues and extends previous findings not only contextually but also substantially by providing more ecologically valid evidence of the reverse $\mathrm{COO}$ effect. Our findings provide a more solid theoretical explanation for the proposed relationships that is based on the memory and online judgment development processes. Furthermore, the current research not only provides more solid support for the reverse $\mathrm{COO}$ effect but also goes a step further and identifies two types of effects (brand and product) and, in doing so, examines their interrelationship.

Second, we take a different methodological approach that allows the stimuli used in reverse inference of CI to emerge naturally rather than to be artificially imposed on respondents. Thus, the current study increases the generalizability of the identified effects and, in accordance with Samiee's (2010) request for ecologically appropriate research designs, our study does not artificially expose participants to brands and their origins. Furthermore, we adopted an experimental methodology to test the causal direction of the effects and overcome the limitations of most previous CI studies that use cross-sectional surveys. The experimental evidence provides more solid support for the direction of the relationship 
Third, we evaluate whether the observed brand effects are contained within the boundaries of the industry of those brands or spill over to the evaluations of the country. Magnusson et al. (2014) partially address this issue but provide inconclusive results. We show that (1) industry image mediates brands' impact on the evaluation of CI, (2) not all industries have an effect on the evaluations of CI, and (3) certain industries are more important than others. Thus, the CI construct should be reconceptualized to account for industry image discrepancies.

Fourth, the study shows that accessibility of information about the brands and products of a country influences CI. Information about widely advertised brands of a country is stored in consumers' memories and can be accessed in the evaluations of the country. This confirms that Tversky and Kahneman's (1973) availability heuristic and Menon and Raghubir's (2003) mere accessibility theory apply in the development of CI.

Fifth, we provide evidence of the scarcely examined differential effect of recollection and familiarity processes on the evaluation of $\mathrm{CI}$, as proposed by the RK (remember-know) paradigm (Gardiner 1988; Hansen and Wänke 2009). The idea of country familiarity that Han (1989) explores, which forms the basis of conceptualizing CI as either a summary construct (once consumers have a deeper knowledge and familiarity with the brands, CI operates as a summary of the consumers' experience with products from a country) or a halo effect (people use CI to make inferences about the country brands, and evaluations of the CI influence their beliefs about the products and attitudes toward the brands from that country). Han's argument is in line with Hastie and Park's (1986) independence model (in which brands stored in memory do not affect CI) for countries with weak country images) depending on the familiarity with the country's brands, needs to be reexamined through the lens of the RK paradigm. 


\section{Managerial implications}

Focusing on practice, governments around the world are increasingly taking a proactive approach to managing the image of their countries (Van Ham, 2001) to promote differentiation, improve tourism, increase inward investment and exports, and gain political influence (Papadopoulos, 2004). Tourism boards, investment promotion agencies, cultural institutes, exporters associations, ministries of foreign affairs, policy makers, and nongovernmental organizations are among the entities driving such country-branding efforts (Anholt, 2007).

This research contributes firstly understanding the positive or negative influence that the image of corporate brands can exert on CI and the factors that are likely to affect this is, therefore, important for tourism boards, ministries of foreign affairs, and other organizations that drive country-branding efforts (Anholt, 2007). Brands such as Samsung, Hyundai, and LG (Korean) transformed the image of their country (Anholt 2000; Van Ham 2001). The importance of these companies in shaping the image of their countries seems to exceed that of sociocultural, economic, and other factors proposed in the relevant literature. The importance of brands becomes evident with respect to the impact of product recalls such as the recall of HP laptops from British outlets over battery overheating fears. Countries should treat their brands as a national asset and ambassadors of their country. They should develop strategies to internationalize successful local brands and provide incentives to ensure that brands aimed at international buyers are free of image flaws that may be harmful to the CI. Countries can do this through product safety and quality standards agencies and/or regulations, compliance standards and policing mechanisms. Local brands should become part of country-branding campaigns. International labeling requirements regarding the origins of a product may not be sufficient to link local brands with their COO, as White (2012) attests. Countries should 
encourage the private sector to use brands or branding strategies that are evocative of the COO.

Second, the results of this research are highly relevant for managers and consultants working on country- (place-) branding campaigns. Italy is associated with food, fashion, and cars, and South Korea is associated with electronics and cars. This study shows that brands and industries can help strengthen the evaluations of the economic dimension of different countries; however, these assets are underdeveloped in country-branding campaigns. Linking countries with brands and industries in such campaigns could result in positive associations, which in turn could enhance the reputational rating of the countries.

Third, the number of brands outside the domestic market is not the only requirement to strengthen the impact of brands on the evaluations of CI. The impact of brands on the evaluation of a country occurs when consumers are aware of both the brand and its COO. Thus, branding can play a significant role in the degree to which consumers identify the brand by COO. Therefore, firms should take a proactive approach, for example, by highlighting their $\mathrm{COO}$ in their corporate visual identity and corporate communication. We urge practitioners to select brands that evoke certain brand associations (i.e., consumers are aware of the brands); have a powerful image (in terms of favourability, strength, and uniqueness); have high national and international visibility; and have an image that reinforces and/or creates desired country image. Practitioners involved in country- (place-) branding campaigns need to carefully consider and monitor these factors in the process of selecting brands that could be used in promoting the CI.

Fourth, strong brands can act as flagships to support the development and enhancement of the image of a country's industry and, in this way, help lesser-known brands in that industry. For such brands, the image of the country's industry may be more relevant and important than the overall evaluations of the country. 


\section{Limitations and further research}

We recognize several limitations of our research at both the theoretical and conceptual level and the research design and methodological level. Similar to other studies in this specific field, the generalizability of the results may be limited because our focus was on evaluations of consumers from only one country (the United Kingdom). Although research in cultural geography (e.g., Casey, 1993) indicates that the effect of places is ubiquitous and transcends cultural setting, it is likely that context-related factors (e.g., the availability of foreign brands in one country) may influence CI evaluations. Batra et al. (2000) find that contextual factors such as the prevalence of materialism and xenocentrism in a country inflate the importance attached to a COO. Further research would benefit from replicating our studies across different countries and with different COOs. For example, using COOs with strong industrial bases and traditions and histories that are closely linked with the Industrial Revolution would likely show a stronger impact of brands and industries on CI.

Further research could examine the influence of brands misidentified as being from the wrong $\mathrm{COO}$ and mistakenly stored as such in consumers' memories. This is the case for Italy, where Italian-sounding names are used widely in the branding of many non-Italian products. It was beyond the scope of this research to examine the influence of such brands on industry image and CI. Further research could examine positive or negative $\mathrm{COO}$ misidentification effects on the attitudinal evaluations of an industry.

Our research also has several methodological limitations. One issue is related to our focus on the activation of local brands to assess their effect on CI in isolation of other cues that may be part of consumers' country schema. This approach may have inflated the effects of brands on CIs. Future research should involve the activation of other country cues in conjunction with the activation of brand cues. Such an approach would allow researchers to examine how brands interact with other country cues in shaping CI. 
We relied on established operationalizations of CI constructs. Although validation and measurement model fit statistics were at acceptable levels, the specification of the CI as reflective constructs should be revisited. Future research should examine the possibility of respesifying CI costructs as formative scales.

This research is in line with the $\mathrm{COO}$ effects literature that assumes that categorical processes are in place such that brands are assigned to a COO. However, evidence from Andéhn and L'Espoir Decosta (2016) suggests that COO may not be a categorical variable but rather an associative one. Brands can be strongly or weakly associated with a COO. Further research could also examine the degree of a brand's association with a $\mathrm{COO}$ or the salience of $\mathrm{COO}$ in the brand's associative network and the effects on CI.

We controlled for familiarity. Given the conflict history and economic competition of both countries, they may be perceived as equivalent in terms of the enmity they produce. However, the likely differences in the strength and nature of the relationships of different consumers with the people of the respective countries may influence CI evaluations.

Finally, we have assumed that consumers consciously reflect on brands and countries. However, Bargh (2002) shows that automatic nonconscious processing may also underlie the cognitive process. Further research would benefit from considering nonconscious processes and should assess implicit attitudes in parallel with explicit attitudes toward the country. 


\section{References}

Ajzen, I. (2001). Nature and operation of attitudes. Annual Review of Psychology, 52(1): 2758.

Alba, J. W., and Hutchinson, J. W. 1987. Dimensions of consumer expertise. Journal of Consumer Research, 13(4): 411-455.

Allport, G. W. (1954). The nature of prejudice. Reading, MA: Addison Wesley.

Andéhn, M. and L'Espoir Decosta, P. (2016). The variable nature of country-to-brand association and its impact on the strength of the country-of-origin effect. International Marketing Review, 33(6), pp.851-866.

Anholt, S. (2000). The Nation as Brand. Across the Board, Nov/Dec, 22-27.

Anholt, S. (2007). Competitive Identity: The New Brand Management for Nations, Cities and Regions. Basingstoke, UK: Palgrave Macmillan.

Baker, R., Blumberg, S. J., Brick, J. M., Couper, M. P., Courtright, M., Dennis, J. M., Dillman, D., Frankel, M. R., Garland, P., Groves, R. M., Kennedy, C., Krosnick, J., and Lavrakas, P. J. (2010). AAPOR report on online panels. The Public Opinion Quarterly, 74(4): 711-781.

Balabanis, G., and Diamantopoulos. A. (2004). Domestic country bias, country-of-origin effects, and consumer ethnocentrism: A multidimensional unfolding approach. Journal of the Academy of Marketing Science, 32(1): 80-95.

Balabanis, G., and Diamantopoulos, A. (2008). Brand origin identification by consumers: A classification perspective. Journal of International Marketing, 16(1): 39-71.

Bar-Tal, D. (1997). Formation and change of ethnic and national stereotypes: An integrative model. International Journal of Intercultural Relations, 21(4): 491-523.

Bargh, J. A. (2002). Losing consciousness: Automatic influences on consumer judgment, behavior, and motivation. Journal of Consumer Research, 29(2), 280-285. 
Batra, R., Ramaswamy, V., Alden, D. L., Steenkamp, J. B. E., and Ramachander, S. (2000). Effects of brand local and nonlocal origin on consumer attitudes in developing countries. Journal of Consumer Psychology, 9(2), 83-95.

Becker, T. E., Atinc, G., Breaugh, J. A., Carlson, K. D., Edwards, J. R., and Spector, P. E. (2016). Statistical control in correlational studies: 10 essential recommendations for organizational researchers. Journal of Organizational Behavior, 37(2): 157-167.

Bernstein, D. (1984). Company image and reality: A critique of corporate communications. Eastbourne, UK: Holt, Rinehart and Winston.

Bowe, J., Lockshin, L., Lee, R., and Rungie, C. (2013). Old dogs, new tricks - Rethinking country - image studies. Journal of Consumer Behaviour, 12(6), 460-471.

Callegaro, M., Villar. A., Yeager, D., and Krosnick, J. A. (2014). A critical review of studies investigating the quality of data obtained with online panels based on probability and nonprobability samples. In Online Panel Research: A Data Quality Perspective (eds M. Callegaro, R. Baker, J. Bethlehem, A. S. Göritz, J. A. Krosnick and P. J. Lavrakas), John Wiley \& Sons, Ltd, Chichester, UK.

Casey, E. S. (1993). Getting back into place: Toward a renewed understanding of the placeworld. Indiana University Press.

Cohen J. (1988). Statistical power analysis for the behavioral sciences (2nd ed.). Hillsdale, NJ: Erlbaum.

Dacin, P.A. and Smith, D.C. (1994). "The effect of brand portfolio characteristics on consumer evaluations of brand extensions.” Journal of Marketing Research, 31 (May): 229-242.

De Liver, Y., van der Pligt, J. and Wigboldus, D. (2007). Positive and negative associations underlying ambivalent attitudes. Journal of Experimental Social Psychology, 43(2), 319326. 
Dowling, G. R. (1993). Developing your company image into a corporate asset. Long Range Planning, 26(2): 101-109.

Dowling, G. R. (1994). Corporate reputations: Strategies for developing the corporate brand. London: Kogan Page.

Dowling, G. R. (2001). Creating corporate reputations: Identity, image and performance. Oxford: Oxford University Press.

Fazio, R. H. (1995). Attitudes as object-evaluation associations: Determinants, consequences, and correlates of attitude accessibility. In Richard E. Petty, Jon A. Krosnick (eds) Attitude strength: Antecedents and consequences, 4, Psychology Press, pp. 247-282.

Fazio, R. H., and Zanna, M. P. (1981). Direct experience and attitude-behavior consistency. In L. Berkowtz (Ed,). Advances in experimental social psychology:161-202. New York: Academic Press.

Fiske, S. T., and Taylor, S. E. (1984). Social Cognition, Random House, New York.

French, A., and Smith, G. (2013). Measuring brand association strength: a consumer based brand equity approach. European Journal of Marketing, 47(8), 1356-1367.

Gardiner, J. M. (1988). Functional aspects of recollective experience. Memory and Cognition, 16: 309-313.

Ghosh, V. E., and Gilboa, A. (2014). What is a memory schema? A historical perspective on current neuroscience literature. Neuropsychologia, 53: 104-114.

Goldberg, L. R. (1986). The validity of rating procedures to index the hierarchical level of categories. Journal of Memory and Language, 25(3): 323-347.

Han, C. M. (1989). Country image: Halo or summary construct? Journal of Marketing Research, 26(2): 222-229. 
Hansen, J., and Wänke, M. (2009). Liking what's familiar: The importance of unconscious familiarity in the mere-exposure effect. Social Cognition, 27(2): 161-182.

Hastie, R., and Park, B. (1986). The relationship between memory and judgment depends on whether the judgment task is memory-based or on-line. Psychological Review, 93(3): $258-268$.

Hayes, A. F. (2012). PROCESS: A versatile computational tool for observed variable mediation, moderation, and conditional process modeling [White paper]. Retrieved from http://www.afhayes.com/public/process2012.pdf

Hepler, J., and Albarracin, D. (2013). Attitudes without objects: Evidence for a dispositional attitude, its measurement, and its consequences. Journal of Personality and Social Psychology, 104(6): 1060.

Heslop, L.A. and Papadopoulos, N. (1993) 'But Who Knows Where or When: Reflections on the Images of Countries and their Products', in N. Papadopoulos and L.A. Heslop (eds.) Product and Country Images: Impact and Role in International Marketing, The Haworth Press: New York, pp: 39-76.

Hsieh, M.H., Pan, S. L., and Setiono, R. (2004). "Product-, corporate-, and country-image dimensions and purchase behavior: A multicountry analysis." Journal of the Academy of Marketing Science, 32 (3), pp. 251-270.

Iversen, N.M. and Hem, L.E. (2008) "Provenance associations as core values of place umbrella brands. A framework of characteristics.” European Journal of Marketing, 42 (5/6), pp.603-626.

Jaffe, E. D., and Nebenzahl, I. D. (2001). National image and competitive advantage: The theory and practice of country-of-origin effect. Copenhagen: Copenhagen Business School Press. 
Jaffe, E. D., and Nebenzahl, I. D. (2006). National image and competitive advantage: The theory and practice of place branding (2nd ed.). Copenhagen: Copenhagen Business School Press.

Josiassen, A., Assaf, A. G., Woo, L., and Kock, F. (2016). “The Imagery-Image Duality Model: An Integrative Review and Advocating for Improved Delimitation of Concepts." Journal of Travel Research, 55 (6), pp. 789-803.

Josiassen, A., Lukas, B. A., and Whitwell, G. J. (2008). “Country-of-origin contingencies: Competing perspectives on product familiarity and product involvement.” International Marketing Review, 25 (4), pp. 423-440.

Josiassen, A., Lukas, B. A., Whitwell, G. J., and Assaf, A. G. (2013). "The halo model of origin images: Conceptualisation and initial empirical test.” Journal of Consumer Behaviour, 12 (4), pp. 253-266.

Keller, K.L. (1993). “Conceptualizing, measuring and managing customer-based brand equity.” Journal of Marketing, 57 (January), pp.1-22.

Kim, C. K. (1995). Brand popularity and country image in global competition: managerial implications. Journal of Product and Brand Management, 4(5): 21-32.

Kim, C. K., and Chung, J. Y. (1997). Brand popularity, country image and market share: An empirical study. Journal of International Business Studies, 28(2): 361-386.

Klein, J. B., Ettenson, R., and Morris, M. D. (1998). The animosity model of foreign product purchase: An empirical test in the People's Republic of China. Journal of Marketing, 62(1): $89-100$.

Krishnan, H. S. (1996). Characteristics of memory associations: A consumer-based brand equity perspective. International Journal of Research in Marketing, 13(4): 389-405. 
Lee, D., and Ganesh, G. (1999). Effects of partitioned country image in the context of brand image and familiarity: A categorization theory perspective. International Marketing Review, 16(1): 18-41.

Lee, R., and Lockshin, L. (2011). Halo effects of tourists' destination image on domestic product perceptions. Australasian Marketing Journal, 19(1), 7-13.

Lee, R., and Lockshin, L. (2012). Reverse country-of-origin effects of product perceptions on destination image. Journal of Travel Research, 51 (4): 502-511.

Lee, R., Lockshin, L., and Greenacre, L. (2016). A memory-theory perspective of countryimage formation. Journal of International Marketing, 24(2): 62-79.

Libelium. (2015). Marca España awards Libelium's CEO Alicia Asín to represent Spanish international talent program online Libelium World, October 9th, 2015. Available at: http://www.libelium.com/marca-espana-awards-libeliums-ceo-alicia-asin-to-representspanish-international-talent-program/ (Accessed: 22 December 2017).

Löhr, J. (2015). Has 'made in Germany' badge been harmed by the Volkswagen scandal? The Guardian, 2 November. Available at:

https://www.theguardian.com/business/2015/nov/02/made-in-germany-harmedvolkswagen-scandal (Accessed: 15 May 2017).

Magnusson, P., Krishnan, V., Westjohn, S. A., and Zdravkovic, S. (2014). The spillover effects of prototype brand transgressions on country image and related brands. Journal of International Marketing, 22(1): 21-38.

Maheswaran, D. (1994). Country of origin as a stereotype: Effects of consumer expertise and attribute strength on product evaluations. Journal of Consumer Research, 21(2): 354-365.

Maheswaran, D., and Chen, C. Y. (2009). Nation equity: Country-of-origin effects and globalization. In Masaaki. K., \& Helsen, K. (Eds.), Handbook of international marketing: 91-113. London: Sage. 
Maneschi, A. (1998). Comparative advantage in international trade: A historical perspective. Cheltenham: Edward Elgar Publishing.

Meade, A. W., and Craig, S. B. (2012). Identifying careless responses in survey data. Psychological Methods, 17(3): 437-455.

Menon, G., and Raghubir, P. 2003. Ease-of-retrieval as an automatic input in judgments: A mereaccessibility framework? Journal of Consumer Research, 30(2): 230-243.

Mimosa Spencer (2017). Bernard Arnault Honored for Promoting French Economic Prestige The ceremony was held at the French foreign affairs ministry. WWD, October 16, 2017 Available at: http://wwd.com/fashion-news/fashion-scoops/bernard-arnault-honored-forpromoting-french-economic-prestige-11028441/ (Accessed: 22 December 2017).

Mossberg, L., and Kleppe, I. A. (2005). Country and destination image-different or similar image concepts?. The Service Industries Journal, 25(4), 493-503.

Nadeau, J., Heslop, L., O’Reilly, N., and Luk, P. (2008). Destination in a country image context. Annals of Tourism Research, 35(1), 84-106.

Nebenzahl, I. D., Jaffe, E. D., and Lampert, S. I. (1997). Towards a theory of country image effect on product evaluation. Management International Review, 37(1): 27-49.

Oberecker, E. M., and Diamantopoulos, A. (2011). Consumers' emotional bonds with foreign countries: Does consumer affinity affect behavioral intentions? Journal of International Marketing, 19(2): 45-72.

Olson, J. C. and Dover, P. A. 1978. Attitude maturation: Changes in related belief structures over time. Advances in Consumer Research, 5: 333-342.

Papadopoulos, N. (1993). What product and country images are and are not. In Papadopoulos, N. \& Heslop, L. (Eds.), Product-country images: Impact and role in international marketing: 3-38. New York: International Business Press.

Papadopoulos, N. (2004), "Place Branding: Evolution, Meaning and Implications”, Place Branding, 1 (1), 36-49. 
Papadopoulos, N. and Heslop, L.A. (eds) (1993) Product-Country Images-Impact and Role in International Marketing, New York: International Business Press.

Pappu, R. and Quester, P. (2010). Country Equity: Conceptualization and Empirical Evidence. International Business Review, 19 (3), 276-91.

Pappu, R., Quester, P. G., and Cooksey, R. W. (2007). Country image and consumer-based brand equity: relationships and implications for international marketing. Journal of International Business Studies, 38: 726-745.

Perlmutter, H. V. (1954). Relations between the self-image, the image of the foreigner, and the desire to live abroad. The Journal of Psychology, 38(1), 131-137.

Pettigrew, T. F., and Tropp, L. R. (2006). A meta-analytic test of intergroup contact theory. Journal of Personality and Social Psychology, 90(5): 751.

Petty, R. E., Briñol, P., and DeMarree, K. G. (2007). The Meta-Cognitive Model (MCM) of attitudes: Implications for attitude measurement, change, and strength. Social Cognition, 25(5): 657-686.

Petty, R. E., Briñol, P., Fabrigar, L. R., and Wegener, D. T. (2019). "Attitude structure and change." In Eli J. Finkel, Roy F. Baumeister (eds) "Advanced Social Psychology: The State of the Science", Oxford University Press, pp 117 -145.

Riezebos, R. (2003) Brand Management. A theoretical and practical approach. Harlow: Prentice Hall.

Rosch, E., Simpson, C., and Miller, R. S. (1976). Structural bases of typicality effects. Journal of Experimental Psychology: Human Perception and Performance, 2(4): 491-502.

Roth, M.S. and Romeo, J.B. (1992) Matching product category and country image perceptions: a framework for managing country-of-origin effects. Journal of International Business Studies, 23 (3): 477-97

Roth, K. P., and Diamantopoulos, A (2009). Advancing the country image construct. Journal of Business Research, 62(7): 726-40. 
Ryu, J. S., Decosta, J. P. L. E., and Andéhn, M. (2016). From branded exports to traveler imports: Building destination image on the factory floor in South Korea. Tourism Management, 52(1), 298-309.

Samiee, Saeed (2010), “Advancing the Country Image Construct - A Commentary Essay," Journal of Business Research, 63 (4), 442-45.

Samiee, S., Shimp, T. A., and Sharma, S. (2005). Brand origin recognition accuracy: Its antecedent and consumers' cognitive limitations. Journal of International Business Studies, 36(4): 379-97.

Schooler, R. D. (1965). Product bias in the Central American common market. Journal of Marketing Research, 2(4), 394-397.

Shimp, T. A., and Sharma, S. (1987). Consumer ethnocentrism: Construction and validation of the CETSCALE. Journal of Marketing Research, 24(3): 280-289.

Story, J.W. (2005). The effects of perceived technological incongruence on perceptions of fit between countries, products and attributes. Journal of Business Research, 58, pp.13101319.

Sun, Q., and Paswan, A. (2011). Country branding using product quality. Journal of Brand Management, 19(2), 143-157.

Tseng, T. H., and Balabanis, G. (2011). Explaining the product-specificity of country-oforigin effects. International Marketing Review, 28(6): 581-600.

Tversky, A., and Kahneman, D. (1973). Availability: A heuristic for judging frequency and probability. Cognitive Psychology, 5: 207-232.

Usunier, J. C., and Cestre, G. (2007). Product ethnicity: Revisiting the match between products and countries. Journal of International Marketing, 15(3): 32-72.

Van Ham, P. (2001). The Rise of the Brand State: The Postmodern Politics of Image and Reputation. Foreign Affairs, 80 (5), 2-6. 
Verlegh, P. W., and Steenkamp, J. B. E. M. (1999). A review and meta-analysis of countryof-origin research. Journal of Economic Psychology, 20(5): 521-546.

White, C. L. (2012). Brands and national image: An exploration of inverse country-of-origin effect. Place Branding and Public Diplomacy, 8(2), 110-118.

Williams, L. J., Hartman, N., and Cavazotte, F. (2010). Method variance and marker variables: A review and comprehensive CFA marker technique. Organizational Research Methods, 13(3): 477-514.

Wilson, T. D., and Kraft, D. (1993). Why do I love thee? Effects of repeated introspections about a dating relationship on attitudes toward the relationship. Personality and Social Psychology Bulletin, 19: 409-418.

Wilson, T. D., Kraft, D., and Dunn, D. S. (1989). The disruptive effects of explaining attitudes: The moderating effect of knowledge about the attitude object. Journal of Experimental Social Psychology, 25(5): 379-400.

Yonelinas, A. P. (2002). The nature of recollection and familiarity: A review of 30 years of research. Journal of Memory and Language, 46(3): 441-517. 


\section{TABLES}

Table 1.

Income distribution of the sample

\begin{tabular}{lrr}
\hline \hline & \multicolumn{2}{c}{ Valid } \\
\hline Less than $£ 10,000$ & 6 & 1.1 \\
$£ 10,000-£ 19,999$ & 49 & 8.8 \\
$£ 20,000-£ 29,999$ & 93 & 16.7 \\
$£ 30,000-£ 39,999$ & 120 & 21.5 \\
$£ 40,000-£ 49,999$ & 98 & 17.6 \\
$£ 50,000-£ 59,999$ & 62 & 11.1 \\
$£ 60,000-£ 69,999$ & 46 & 8.3 \\
$£ 70,000-£ 79,999$ & 23 & 4.1 \\
$£ 80,000-£ 89,999$ & 18 & 3.2 \\
$£ 90,000-£ 99,999$ & 13 & 2.3 \\
$£ 100,000-£ 109,999$ & 15 & 2.7 \\
$£ 110,000-£ 119,999$ & 1 & .2 \\
$£ 120,000-£ 129,999$ & 5 & .9 \\
$£ 130,000-£ 139,999$ & 0 & 0 \\
$£ 140,000-£ 149,999$ & 1 & .2 \\
$£ 150,000-£ 159,999$ & 4 & .7 \\
$£ 160,000-£ 169,999$ & 0 & 0 \\
$£ 170,000-£ 179,999$ & 1 & .2 \\
$£ 180,000-£ 219,999$ & 0 & 0 \\
More than $£ 220,000$ & 2 & .4 \\
Total & 557 & 100.0 \\
\hline \hline
\end{tabular}


Table 2.

Summary of hypotheses tests

\begin{tabular}{|c|c|c|c|}
\hline Hypotheses & Relationship & Analysis & Results \\
\hline $\begin{array}{l}\text { H1. Information about a country's } \\
\text { brands retrieved from memory } \\
\text { influences (a) product-related CI and (b) } \\
\text { general CI. }\end{array}$ & Brand $\rightarrow$ CI & $\begin{array}{l}\text { Linear } \\
\text { mixed } \\
\text { models }\end{array}$ & Supported \\
\hline $\begin{array}{l}\text { H2. The valence ratio of a country's } \\
\text { brands retrieved from memory } \\
\text { positively influences (a) product-related } \\
\text { CI and (b) general CI. }\end{array}$ & Brand $\rightarrow$ CI & $\begin{array}{l}\text { Hierarchical } \\
\text { regression }\end{array}$ & $\begin{array}{l}\text { Partially } \\
\text { supported }\end{array}$ \\
\hline $\begin{array}{l}\text { H3. Information about a country's } \\
\text { brands retrieved from memory } \\
\text { influences the corresponding industry } \\
\text { image. }\end{array}$ & $\begin{array}{l}\text { Brand } \rightarrow \\
\text { Industry image }\end{array}$ & ANCOVA & $\begin{array}{l}\text { Partially } \\
\text { supported }\end{array}$ \\
\hline $\begin{array}{l}H 4 \text {. The valence ratio of the retrieved } \\
\text { brands from the evaluated industry of a } \\
\text { country positively influences the } \\
\text { corresponding industry image. }\end{array}$ & $\begin{array}{l}\text { Brand } \rightarrow \\
\text { Industry image }\end{array}$ & $\begin{array}{l}\text { Hierarchical } \\
\text { regression }\end{array}$ & $\begin{array}{l}\text { Partially } \\
\text { supported }\end{array}$ \\
\hline $\begin{array}{l}\text { H5. Information about a country's } \\
\text { products retrieved from memory } \\
\text { influences (a) product-related CI and (b) } \\
\text { general CI. }\end{array}$ & Product $\rightarrow$ CI & $\begin{array}{l}\text { Linear } \\
\text { mixed } \\
\text { models }\end{array}$ & Supported \\
\hline $\begin{array}{l}\text { H6. Information about a country's } \\
\text { products retrieved from memory } \\
\text { influences the corresponding industry } \\
\text { image. }\end{array}$ & $\begin{array}{l}\text { Product } \rightarrow \\
\text { Industry image }\end{array}$ & ANCOVA & $\begin{array}{l}\text { Partially } \\
\text { supported }\end{array}$ \\
\hline $\begin{array}{l}\text { H7. The effect of recalled brands on the } \\
\text { corresponding industry image is } \\
\text { stronger than the corresponding effect } \\
\text { on CI. }\end{array}$ & $\begin{array}{l}\text { Brand } \rightarrow \\
\text { Industry image } \\
\text { vs Brand } \rightarrow \text { CI }\end{array}$ & Size effects & Supported \\
\hline $\begin{array}{l}\text { H8. The effect of recalled brands on CI } \\
\text { is weaker than the effect of the pertinent } \\
\text { industries' image on CI. }\end{array}$ & $\begin{array}{l}\text { Brand } \rightarrow \text { CI vs } \\
\text { Industry image } \\
\rightarrow \text { CI }\end{array}$ & Size effects & $\begin{array}{l}\text { Not } \\
\text { supported }\end{array}$ \\
\hline $\begin{array}{l}\text { H9. The effect of recalled brands on the } \\
\text { general CI of NICs is stronger than that } \\
\text { on the general CI of economically } \\
\text { advanced countries. }\end{array}$ & Brand $\rightarrow$ CI & $\begin{array}{l}\text { Linear } \\
\text { mixed } \\
\text { models }\end{array}$ & $\begin{array}{l}\text { Not } \\
\text { supported }\end{array}$ \\
\hline
\end{tabular}


Table 3.

Linear mixed-effects model analysis results (brand effects)

\begin{tabular}{|c|c|c|c|c|c|c|c|c|c|c|}
\hline & & $\begin{array}{c}\text { General CI } \\
\text { (economic- } \\
\text { technological) }\end{array}$ & & & $\begin{array}{l}\text { General CI } \\
\text { (political) }\end{array}$ & & & $\begin{array}{l}\text { Product- } \\
\text { related CI }\end{array}$ & & \\
\hline Source & $\begin{array}{c}\text { Numerator } \\
\text { d.f. } \\
\end{array}$ & $\begin{array}{c}\text { Denominator } \\
\text { d.f. } \\
\end{array}$ & $\mathrm{F}$ & Sig. & $\begin{array}{c}\text { Denominator } \\
\text { d.f. } \\
\end{array}$ & $\mathrm{F}$ & Sig. & $\begin{array}{c}\text { Denominator } \\
\text { d.f. } \\
\end{array}$ & $\mathrm{F}$ & Sig. \\
\hline Intercept & 1 & 243.883 & 269.430 & .000 & 245.267 & 146.389 & .000 & 243.870 & 403.542 & .000 \\
\hline CI development process & 1 & 375.559 & 4.623 & .032 & 393.421 & 1.988 & .159 & 378.403 & 5.179 & .023 \\
\hline Stimulus country & 1 & 337.454 & 7.292 & .007 & 318.794 & 21.105 & .000 & 336.355 & .046 & .830 \\
\hline $\begin{array}{l}\text { CI development process } \times \\
\text { Country }\end{array}$ & 1 & 339.648 & 1.368 & .243 & 320.569 & 2.087 & .149 & 334.219 & 7.815 & .005 \\
\hline Familiarity(country) & 2 & 434.815 & 17.990 & .000 & 417.479 & 14.960 & .000 & 432.645 & 40.329 & .000 \\
\hline $\begin{array}{l}\text { Familiarity (CI development } \\
\text { process [country]) }\end{array}$ & 2 & 436.027 & .609 & .544 & 419.327 & 2.518 & .082 & 433.983 & .565 & .569 \\
\hline Consumer ethnocentrism & 1 & 223.582 & 2.969 & .086 & 223.864 & 2.193 & .140 & 223.355 & 9.371 & .002 \\
\hline Gender & 1 & 226.620 & 3.499 & .063 & 226.519 & 8.131 & .005 & 226.335 & .092 & .761 \\
\hline Income & 1 & 221.553 & 4.615 & .033 & 221.768 & 5.442 & .021 & 221.312 & 2.108 & .148 \\
\hline Age & 1 & 223.588 & .979 & .324 & 223.949 & 4.875 & .028 & 223.374 & 6.347 & .012 \\
\hline $\begin{array}{l}\text { Schwarz's Bayesian } \\
\text { information criterion }\end{array}$ & & 1570.01 & & & 1698.817 & & & 1334.71 & & \\
\hline
\end{tabular}


Table 4.

Regression analysis for Italian brands (bootstrapped and heteroskedasticity-consistent estimation of SE)

\begin{tabular}{|c|c|c|c|c|c|c|}
\hline & $\begin{array}{l}\text { Product- } \\
\text { related CI }\end{array}$ & $\begin{array}{l}\text { General CI } \\
\text { (economic- } \\
\text { technological) }\end{array}$ & $\begin{array}{l}\text { General } \\
\text { CI } \\
\text { (political) }\end{array}$ & $\begin{array}{l}\text { Food } \\
\text { industry }\end{array}$ & $\begin{array}{l}\text { Auto- } \\
\text { mobile }\end{array}$ & $\begin{array}{l}\text { Fashion } \\
\text { industry }\end{array}$ \\
\hline & Beta & Beta & Beta & Beta & Beta & Beta \\
\hline (Constant) & $5.380^{*}$ & $5.764 *$ & $6.334^{*}$ & $7.043^{*}$ & $5.634^{*}$ & 7.043 \\
\hline Valence ratio & $.467 *$ & -.090 & .014 & $.898 *$ & .374 & $.898^{*}$ \\
\hline Country familiarity & $.158 *$ & .106 & $.144+$ & .003 & -.072 & .003 \\
\hline Familiarity $\times$ valence ratio & .190 & .097 & -.244 & .245 & .164 & .245 \\
\hline Number of brands recalled & .013 & .076 & -.067 & .038 & -.075 & .038 \\
\hline $\begin{array}{l}\text { Familiarity } \times \text { number of brands } \\
\text { recalled }\end{array}$ & -.025 & .011 & $.064+$ & .008 & .051 & .008 \\
\hline Consumer ethnocentrism & -.136 & -.140 & -.192 & $-.342 *$ & $-.204 *$ & $-.342 *$ \\
\hline Gender (dummy) & .202 & -.005 & -.255 & .199 & .345 & .199 \\
\hline Age & .002 & -.004 & .002 & .008 & -.001 & .008 \\
\hline Income & $-.054 *$ & -.070 & -.108 & -.036 & .047 & -.036 \\
\hline $\mathrm{R}^{2}$ & $.223^{*}$ & .113 & .113 & $.424^{*}$ & $.207^{*}$ & $.424^{*}$ \\
\hline$\Delta \mathrm{R}_{1}^{2}$ & .014 & .002 & .009 & .016 & .005 & .016 \\
\hline$\Delta \mathrm{R}_{2}^{2}$ & .009 & .001 & $.023+$ & .001 & .031 & .001 \\
\hline$\Delta \mathrm{R}_{3}{ }^{2}$ & .019 & .005 & $.028+$ & .018 & .033 & .018 \\
\hline
\end{tabular}

Notes: $\Delta \mathrm{R}^{2}=\mathrm{R}$-square increase due to interactions, $\Delta \mathrm{R}_{1}^{2}=$ due to familiarity $\times$ valence ratio;

$\Delta \mathrm{R}_{2}{ }^{2}=$ due to familiarity $\times$ number of brands recalled interaction; $\Delta \mathrm{R}_{3}{ }^{2}=$ due to both interactions. ${ }^{*} p<.05$. 
Table 5.

Regression analysis for South Korean brands (bootstrapped and heteroskedasticity-consistent estimation of SE)

\begin{tabular}{|c|c|c|c|c|c|}
\hline & $\begin{array}{l}\text { Product- } \\
\text { related CI }\end{array}$ & $\begin{array}{l}\text { General CI } \\
\text { (economic- } \\
\text { technological) }\end{array}$ & $\begin{array}{l}\text { General CI } \\
\text { (political) }\end{array}$ & $\begin{array}{l}\text { Electr. } \\
\text { industry }\end{array}$ & $\begin{array}{l}\text { Autom. } \\
\text { industry }\end{array}$ \\
\hline & Beta & Beta & Beta & Beta & Beta \\
\hline (Constant) & $4.739 *$ & $5.081^{*}$ & 3.465 & 6.301 & 3.822 \\
\hline Valence ratio & $.890^{*}$ & $.821^{*}$ & .516 & .407 & .092 \\
\hline Country familiarity & $.258^{*}$ & $.211^{*}$ & .181 & .161 & .298 \\
\hline Familiarity $\times$ valence ratio & -.098 & -.154 & -.183 & -.041 & .125 \\
\hline Number of brands recalled & $.217^{*}$ & $.238^{*}$ & .075 & .142 & .039 \\
\hline Familiarity $\times$ number of brands recalled & -.103 & .023 & .036 & .087 & -.118 \\
\hline Consumer ethnocentrism & -.042 & .037 & .155 & -.160 & -.040 \\
\hline Gender (dummy) & -.146 & -.272 & -.412 & -.157 & .442 \\
\hline Age & .014 & .002 & .028 & .011 & .010 \\
\hline Income & -.016 & -.018 & -.008 & -.045 & .031 \\
\hline $\mathrm{R}^{2}$ & $.446^{*}$ & $.273 *$ & $.143+$ & .224 & .171 \\
\hline$\Delta \mathrm{R}_{1}^{2}$ & .001 & .002 & .002 & .000 & .001 \\
\hline$\Delta \mathrm{R}_{2}^{2}$ & .011 & .000 & .001 & .011 & .013 \\
\hline$\Delta \mathrm{R}_{3}^{2}$ & .030 & .002 & .002 & .014 & .014 \\
\hline
\end{tabular}

Notes: $\Delta \mathrm{R}^{2}=\mathrm{R}$-square increase due to interactions, $\Delta \mathrm{R}_{1}{ }^{2}=$ due to familiarity $\times$ valence ratio;

$\Delta \mathrm{R}_{2}{ }^{2}=$ due to familiarity $\times$ number of brands recalled interaction; $\Delta \mathrm{R}_{3}{ }^{2}=$ due to both interactions.

$* p<.05$. 
Table 6.

Linear mixed-effects model analysis results (product effects)

\section{Type III tests of fixed effects}

\begin{tabular}{|c|c|c|c|c|c|c|c|c|c|c|}
\hline & & $\begin{array}{c}\text { General CI } \\
\text { (economic- } \\
\text { technological) }\end{array}$ & & & $\begin{array}{c}\text { General CI } \\
\text { (political) }\end{array}$ & & & $\begin{array}{l}\text { Product- } \\
\text { related CI }\end{array}$ & & \\
\hline Source & $\begin{array}{l}\text { Numerator } \\
\text { d.f. }\end{array}$ & $\begin{array}{l}\text { Denominator } \\
\text { d.f. }\end{array}$ & $\mathrm{F}$ & Sig. & $\begin{array}{l}\text { Denominator } \\
\text { d.f. }\end{array}$ & $\mathrm{F}$ & Sig. & $\begin{array}{l}\text { Denominator } \\
\text { d.f. }\end{array}$ & $\mathrm{F}$ & Sig. \\
\hline Intercept & 1 & 245.035 & 251.912 & .000 & 246.613 & 131.440 & .000 & 245.423 & 333.674 & .000 \\
\hline CI development process & 1 & 376.193 & 4.714 & .031 & 408.613 & 4.534 & .034 & 386.506 & 8.139 & .005 \\
\hline Stimulus country & 1 & 343.993 & 19.216 & .000 & 305.571 & 48.641 & .000 & 332.214 & 16.325 & .000 \\
\hline $\begin{array}{l}\text { CI development process } \times \\
\text { Stimulus country }\end{array}$ & 1 & 346.166 & .088 & .766 & 307.116 & .178 & .674 & 334.242 & .580 & .447 \\
\hline Familiarity (Stimulus country) & 2 & 439.378 & 17.758 & .000 & 400.239 & 16.740 & .000 & 431.528 & 34.150 & .000 \\
\hline $\begin{array}{l}\text { Familiarity (CI development } \\
\text { process [country]) }\end{array}$ & 2 & 439.870 & 1.032 & .357 & 401.453 & 2.184 & .114 & 432.253 & 1.355 & .259 \\
\hline Consumer ethnocentrism & 1 & 221.724 & 3.117 & .079 & 221.284 & 2.749 & .099 & 221.247 & 4.870 & .028 \\
\hline Gender & 1 & 227.953 & 7.184 & .008 & 226.630 & 29.141 & .000 & 227.263 & .174 & .677 \\
\hline Income & 1 & 223.623 & .746 & .389 & 222.920 & .188 & .665 & 223.085 & .316 & .575 \\
\hline Age & 1 & 222.259 & 2.124 & .146 & 221.526 & 7.007 & .009 & 221.694 & 7.415 & .007 \\
\hline $\begin{array}{l}\text { Schwarz's Bayesian information } \\
\text { criterion }\end{array}$ & & 1548.84 & & & 1644.48 & & & 1332.47 & & \\
\hline
\end{tabular}


Figure 1.

Conceptual framework

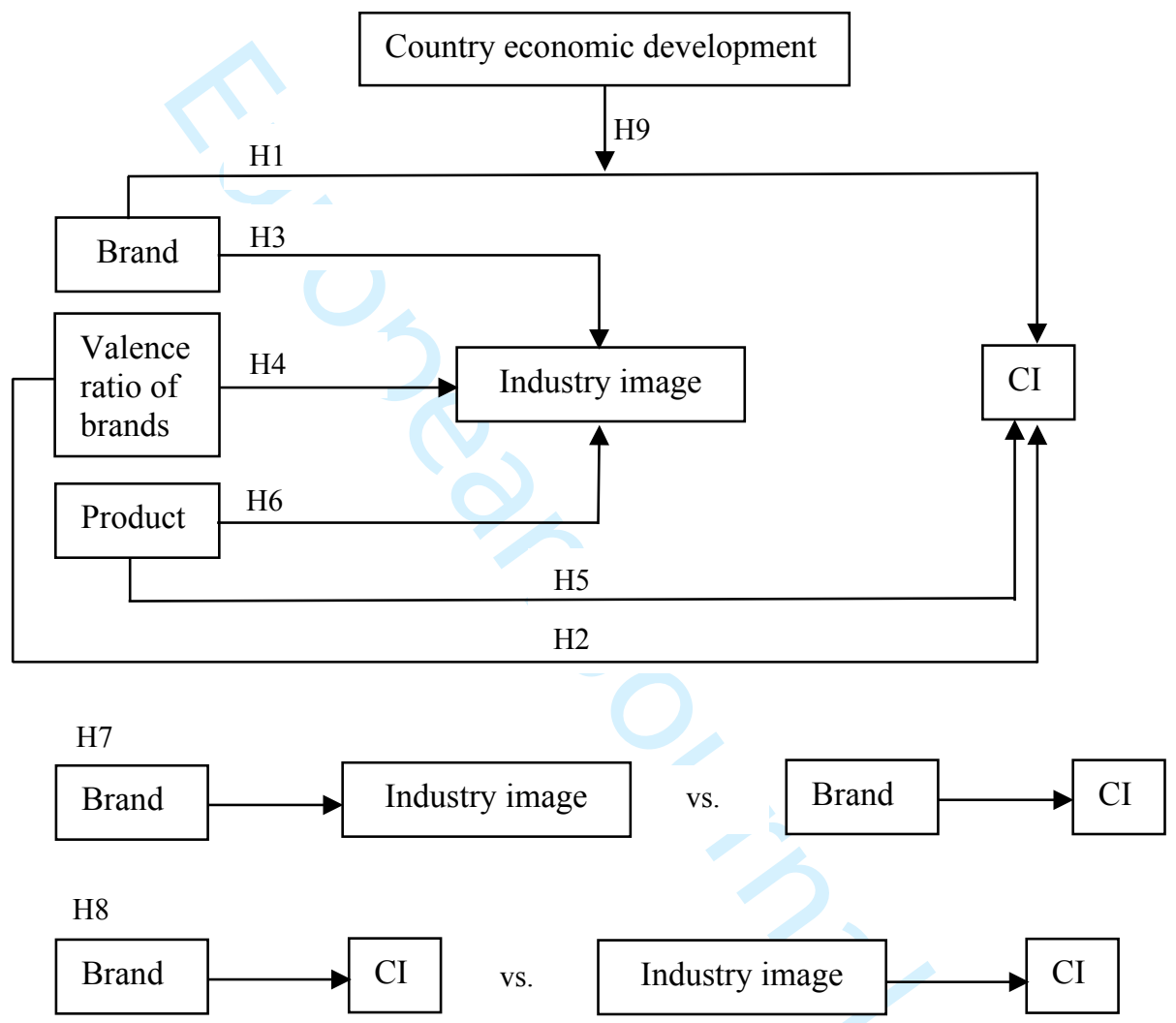


Figure 2. Interaction between familiarity and experimental conditions on Italian automobile industry image

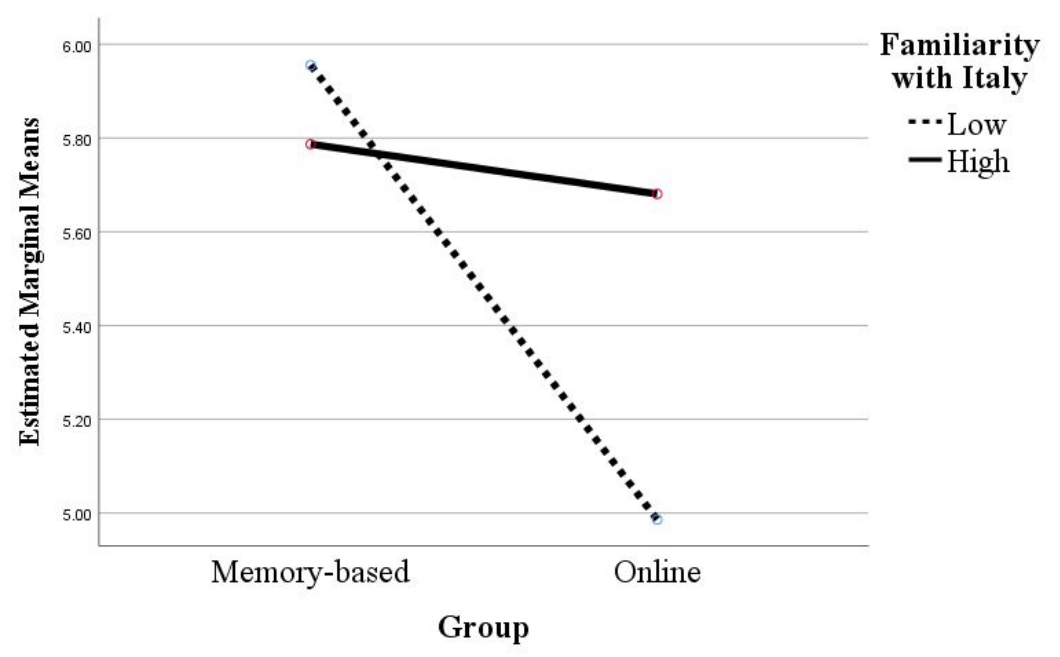

Figure 3. Interaction between familiarity and experimental conditions on South Korean electronics industry image

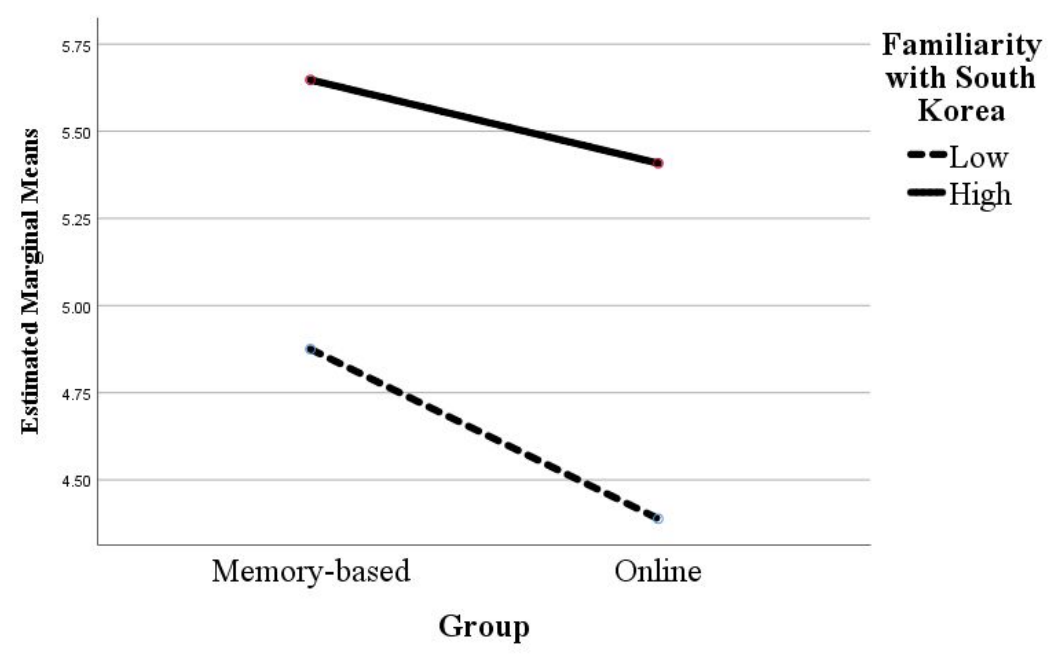




\section{Appendix A.}

A.1 Items, factor loading, AVE and rho

\begin{tabular}{|c|c|c|c|}
\hline & Loading & AVE & Joreskog rho \\
\hline \multicolumn{4}{|l|}{ Italy: General CI } \\
\hline Developed economy & .706 & & \\
\hline Industrialization & .532 & & \\
\hline Technological research & .693 & & \\
\hline High standard of living & .755 & .458 & .769 \\
\hline Civilian government & .774 & & \\
\hline Free-market system & .507 & & \\
\hline Democratic & .734 & .465 & .717 \\
\hline \multicolumn{4}{|l|}{ South Korea: General CI } \\
\hline Developed economy & .918 & & \\
\hline Industrialization & .729 & & \\
\hline Technological research & .746 & & \\
\hline High standard of living & .804 & .644 & .878 \\
\hline Civilian government & .877 & & \\
\hline Free-market system & .816 & & \\
\hline Democratic & .901 & .749 & .899 \\
\hline \multicolumn{4}{|l|}{ Italy: Product-related CI } \\
\hline $\begin{array}{l}\text { Products made in Italy are carefully produced and have fine } \\
\text { workmanship. }\end{array}$ & .841 & & \\
\hline $\begin{array}{l}\text { Products made in Italy show a very high degree of } \\
\text { technological advancement. }\end{array}$ & .727 & & \\
\hline $\begin{array}{l}\text { Products made in Italy usually show a very clever use of color } \\
\text { and design. }\end{array}$ & .703 & & \\
\hline $\begin{array}{l}\text { Products made in Italy are usually quite reliable and seem to } \\
\text { last the desired length of time. }\end{array}$ & .784 & & \\
\hline Products made in Italy are up-market. & .813 & & \\
\hline Products made in Italy are usually a good value for the money. & .635 & .568 & .887 \\
\hline \multicolumn{4}{|l|}{ South Korea: Product-related CI } \\
\hline $\begin{array}{l}\text { Products made in South Korea are carefully produced and have } \\
\text { fine workmanship. }\end{array}$ & .876 & & \\
\hline $\begin{array}{l}\text { Products made in South Korea show a very high degree of } \\
\text { technological advancement. }\end{array}$ & .865 & & \\
\hline $\begin{array}{l}\text { Products made in South Korea usually show a very clever use } \\
\text { of color and design. }\end{array}$ & .757 & & \\
\hline $\begin{array}{l}\text { Products made in South Korea are usually quite reliable and } \\
\text { seem to last the desired length of time. }\end{array}$ & .904 & & \\
\hline Products made in South Korea are up-market. & .787 & & \\
\hline $\begin{array}{l}\text { Products made in South Korea are usually a good value for the } \\
\text { money. }\end{array}$ & .815 & .698 & .933 \\
\hline \multicolumn{4}{|l|}{ Italy: Familiarity } \\
\hline Familiar with Italy & .892 & & \\
\hline Knowledgeable of Italy & .972 & .87 & .930 \\
\hline \multicolumn{4}{|l|}{ South Korea: Familiarity } \\
\hline Familiar with South Korea & .946 & & \\
\hline Knowledgeable of South Korea & .927 & .877 & .935 \\
\hline
\end{tabular}




\begin{tabular}{|l|r|r|r|}
\hline Consumer Ethnocentrism & & & \\
\hline $\begin{array}{l}\text { It is not right to purchase foreign products because it puts } \\
\text { Britons out of jobs. }\end{array}$ & .896 & & \\
\hline A real Briton should always buy British-made products. & .812 & & \\
\hline $\begin{array}{l}\text { Britons should purchase products manufactured in the U.K. } \\
\text { instead of letting other countries get rich off us. }\end{array}$ & .85 & & \\
\hline $\begin{array}{l}\text { Britons should not buy foreign products because this hurts } \\
\text { British business and causes unemployment. }\end{array}$ & .868 & & \\
\hline I always prefer domestic products over foreign ones. & .67 & .677 & \\
\hline Italian automobile industry image & & & \\
\hline Competitive internationally & .829 & & \\
\hline Prestigious & .904 & & \\
\hline High quality & .935 & & \\
\hline Up-market & .887 & .791 & \\
\hline Italian fashion industry image & & & \\
\hline Competitive internationally & .868 & & \\
\hline Prestigious & .952 & & \\
\hline High quality & .883 & & \\
\hline Up-market & .914 & .819 & \\
\hline Italian food industry image & & & \\
\hline Competitive internationally & .838 & & \\
\hline Prestigious & .83 & & \\
\hline High quality & .969 & & \\
\hline Up-market & .819 & .704 & \\
\hline South Korean electronics industry image & .658 & & \\
\hline Competitive internationally & .789 & & .905 \\
\hline Prestigious & .844 & & \\
\hline High quality & .954 & .711 & \\
\hline Up-market & & & \\
\hline South Korean automobile industry image & & \\
\hline Competitive internationally & & \\
\hline Prestigious & & \\
\hline High Quality & & \\
\hline Up-market & & \\
\hline
\end{tabular}

